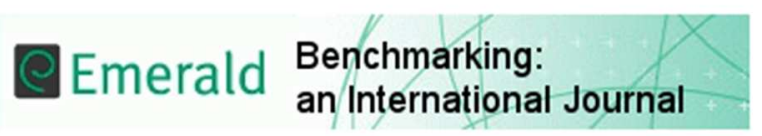

\title{
Green Supply Chain Management: Theoretical Framework and Further Research Directions
}

\begin{tabular}{|r|l|}
\hline Journal: & Benchmarking: an International Journal \\
\hline Manuscript ID & BIJ-01-2016-0011.R2 \\
\hline Manuscript Type: & Original Article \\
\hline Keywords: & Business performance, Supply chain, Competitive Advantage \\
\hline \multicolumn{2}{|c}{} \\
\hline
\end{tabular}

SCHOLARONE ${ }^{\text {In }}$

Manuscripts 


\title{
Green Supply Chain Management: Theoretical Framework and Further Research Directions
}

\begin{abstract}
:
Purpose: Green or sustainable supply chain management (GSCM) has in recent years attracted much attention from academia and practitioners in all part of the world. In recent years, all humanity has experienced severe climate change which is widely attributed to human activity. Harmful emissions have made a major contribution to recent climate change which presents major challenges and threats to the entire human race in form of global warming, earthquakes, hurricanes, tsunami, and floods. The aim of this paper is to propose a conceptual GSCM framework grounded in Knowledge Based Theory (KBT) and outlined further research directions which can take existing GSCM literature to a next level.
\end{abstract}

Design/Methodology/Approach: In this paper we have used a systematic literature review to identify building blocks of the conceptual framework, which is the principal contribution of the present paper.

Findings: In this paper we have proposed a conceptual framework for green supply chain network which is firmly grounded in organizational theory. This framework can be further tested using data collected from multiple organizations using split-questionnaire.

Research implications: The current paper is an attempt to develop a conceptual framework which is grounded in KBT. The study helps to extent the prior works which lacks theory focused approach.

Key-Words: Green Supply Chain Management, Sustainable Supply Chain, Organizational Theories, Systematic Literature Review 
Key-Words: Green Supply Chain Management, Sustainable Supply Chain, Organizational Theories, Systematic Literature Review

\section{Introduction}

Over the last decade, many companies around the world have been implementing Green Supply Chain Management (GSCM) as ways to enhance their competitive edge in the global market (Rao and Holt, 2005; Corbett and Klassen, 2006). There is growing evidence of empirical research supporting a direct relationship between the adoption of Green Supply Chain Management (GSCM) and improved firm performance (e.g. Rao and Holt, 2005; Zhu et al., 2005; Zhu and Sarkis, 2007; Zhu et al., 2008; Eltayeb et al., 2011; Lee et al., 2012; Dues et al., 2013; Gavronski et al., 2013; Dubey and Bag, 2013; Laosirihongthong et al., 2013; Yusuf et al., 2013; Schrettle et al., 2014; Mitra and Datta, 2014; Mohanty and Prakash, 2014a, 2014b; Luthra et al. 2015; Jayaram, and Avittathur, 2015; Malviya and Kant, 2015;Dubey et al. 2015b; Bhardwaj, 2016). Given the theoretical link that exists between competitive advantage and performance, it is perhaps not too surprising that it has been claimed that GSCM or SCSM practices can be used to generate competitive advantage (e.g. Porter and van der Linde, 1995; Gunasekaran and Spalanzani, 2012; Hassini et al., 2012; Giovanni, 2012; Gardas and Narkhede, 2013; Schrettle et al., 2014). Similarly, GSCM has, over the last decade, attracted enormous contributions from researchers around the world. The appeal of GSCM and SSCM is strong because of their growing stature in corporations and increasing recognition from producers and consumers; however, there is a wide gap in the existing literature and corporate policies related to GSCM and SSCM (Hu et al., 2010). The fact remains that there is no comprehensive theoretical model to underpin the claims advanced for GSCM. Without sound supporting theory, it will be difficult to move GSCM research to the next level. Therefore, the objective of our present research is to fill the existing void that still exists between GSCM practices, competitive advantage and organizational performance. 
Theory building in GSCM has attracted the attention of researchers in the past (e.g. Zhu and Sarkis, 2004; Rao and Holt, 2005; Zhu and Sarkis, 2007; Zhu et al., 2012; Shi et al., 2012; Schrettle et al., 2014); however, in the early 2000s there were efforts to develop the theory in the context of or environmental practices including environmental purchasing and their impacts on organizational performance (e.g. Cordeiro and Sarkis, 1997; Sarkis, 1998; Zsidisin and Siferd, 2001; Carter and Jenning, 2002). Most of the models or theoretical frameworks were proposed at the macro level (i.e. institutional pressures - Zhu and Sarkis, 2007; Linton et al., 2007; Bjorklund, 2012; Kauppi, 2013) or at the micro level, including supplier relationship management (Vachon and Klassen, 2006; Bai and Sarkis, 2010; Testa and Iraldo, 2010; Hoof and Lyon, 2013); Lean Manufacturing (Farish, 2009; Franchetti et al., 2009; Deif, 2011; Dues et al., 2013); Total Quality Management (e.g. Pauli, 1997; Murovec et al., 2012; Prajogo et al., 2012; Pereira-Moliner et al., 2012; Gavronski et al., 2013); Leadership (Siaminwe et al., 2005; Stone, 2006; Brown and Stone, 2007; Berkel, 2007; Deif, 2011; Dues et al., 2013; Hoof and Lyon, 2013; Despeisse et al., 2012); and green technology (e.g. Sikdar and Howell, 1998; Zhang et al., 2013; Hoof and Lyon, 2013). However, despite these works at both macro and micro levels, there is nevertheless no comprehensive framework which has investigated the impacts of all these variables on organizational performance under the effect of controllable variables while taking into account environmental uncertainties (Chen and Paulraj, 2004) and product complexities (Jacobs, 2013).

Thus, in this paper we posit three key questions: $R Q 1:$ What are the key constructs of GSCM practices?

RQ2: Can we propose a comprehensive framework for GSCM implementation?

RQ3: What are further research directions?

In an attempt to answer these three key questions, we have adopted a systematic literature review approach. In this way we will be able address the longstanding calls of previous researchers. To this end, the rest of paper is 
organized as follows. In the following section we will discuss the evolution of GSCM practices, including definitions of GSCM based on scholarly works; dimensions of GSCM; theories of GSCM; and the impacts of GSCM practices on organizational performance. Section three will discuss the research methodology and will deliberate on the systematic literature review approach. Section four discusses generic research concerns with GSCM, and in section five, which concludes the paper, we will provide further research directions based on a synthesis of our findings.

\section{Evolution of GSCM}

The traditional supply chain was managed with the objectives of reducing cost and improving service with little concern with environmental dimensions (Simpson et al., 2007; Sarkis et al., 2011). However, over time, external pressures such as coercive pressure, peer pressure and mimetic pressure have forced companies to design supply chain networks which take into account environmental dimensions (Srivastava, 2007; Gavronski et al., 2008; Guide and Van Wassenhove, 2009; Gunasekaran and Spalanzani, 2012). In the last decade, the concept of closed loop supply chains has emerged, reflecting the profit recovery available from value added components, product reuse, and business opportunities in recycling (Guide and Van Wassenhove, 2009; Soleimani et al., 2014). Despite the environmental awareness which emerged in the USA in the 1960s and subsequently spread throughout the world (Sarkis, 2011; Nelson et al., 2013), countries like India and China have been late in responding to the environmental call; however, most firms in India have now integrated environmental dimensions into their corporate policies, although some have yet to implement these. GSCM practices were initially guided by a single objective, i.e. environmental performance. However, in recent years firms have realized that this single objective philosophy cannot provide sustainability. Thus, responding to calls from academics that have long been pending, firms have increasingly started to adoptive more comprehensive performance frameworks, such as the Triple Bottom Line (TBL) (e.g.Awaysheh 
and Klassen, 2010; Paulraj and de Jong, 2011; Giminez et al., 2012; Giovanni, 2012; Hollos et al., 2012). In a similar approach, Carter and Rogers (2008) defined SSCM as a common region defined by three intersecting circles representing financial, social and environmental performance. Thus, we can conclude that the way in which, over the past two decades, SCM has evolved into SSCM and GSCM represents a journey, guided by institutional pressure and the vested interests of the firms, to place these concepts among the guiding philosophies of firms operating in a global environment today.

\subsection{Definitions of GSCM}

In this section, we have made an effort to define GSCM based on past scholarly works, limiting our analysis to those published in the last fifteen years. Table 1 presents some of the definitions presented in the literature.

\section{Table1: Selected definitions of Green Supply Chain Management}

\begin{tabular}{|l|l|}
\hline Reference & Definition \\
\hline $\begin{array}{l}\text { Narasimhan and Carter } \\
\text { (1998) }\end{array}$ & $\begin{array}{l}\text { GSCM is a purchasing philosophy which is guided } \\
\text { by two perspectives. One is reuse and the second is } \\
\text { recycling of materials. }\end{array}$ \\
\hline Godfrey (1998) & $\begin{array}{l}\text { GSCM is a set of practices that helps firm to } \\
\text { monitor environmental dimensions in a supply } \\
\text { chain network and continuously improve supply } \\
\text { chain performance. }\end{array}$ \\
\hline Beamon (1999) & $\begin{array}{l}\text { GSCM is defined as cooperative initiatives, taken by } \\
\text { a central company among supply chain partners, to } \\
\text { support the organization of eco management know- } \\
\text { how in the central company and the development of } \\
\text { clean manufacturing techniques. }\end{array}$ \\
\hline Gilbert (2000) & $\begin{array}{l}\text { GSCM is defined as an integration of environmental } \\
\text { criteria with the traditional supply chain network by } \\
\text { redesigning purchasing policies and involving } \\
\text { suppliers in the entire procurement process. }\end{array}$ \\
\hline
\end{tabular}


\begin{tabular}{|l|l|} 
Kogg (2003) & GSCM is defined as a set of policies that imbibe
\end{tabular} environmental concerns right from product design, procurement, production, distribution, to re-use or disposal of goods or services. This definition is an adapted version of Zsidisin and Sieferd (2001).

\begin{tabular}{l}
\hline Sarkis (2003) \\
\hline $\begin{array}{l}\text { Vachon and Klassen } \\
(2006)\end{array}$
\end{tabular}

GSCM is defined as a combination of the activities of an environmental company and reverse logistics, and emphasized the latter's importance.

GSCM is defined as a strategy, which helps to minimize wastages in supply chain network.

\begin{tabular}{|c|c|}
\hline Srivastava (2007) & $\begin{array}{l}\text { GSCM is defined as a process of integrating } \\
\text { environmental thinking into supply chain } \\
\text { management, including product design, material } \\
\text { sourcing and selection, manufacturing processes, } \\
\text { delivery of the final product to consumers, and end- } \\
\text { of-life management of the product after its useful } \\
\text { life. }\end{array}$ \\
\hline Carter and Rogers (2008) & $\begin{array}{l}\text { GSCM is defined as an integration of environmental } \\
\text { dimensions with the traditional supply chain } \\
\text { network. }\end{array}$ \\
\hline $\begin{array}{l}\text { Seuring and Müller's } \\
(2008)\end{array}$ & $\begin{array}{l}\text { GSCM is defined as the management of material, } \\
\text { information, and capital flows as well as cooperation } \\
\text { among companies along the supply chain while } \\
\text { taking into account goals from all three dimensions } \\
\text { of sustainable development, i.e. economic, } \\
\text { environmental, and social, which are derived from } \\
\text { customer and stakeholder requirements. }\end{array}$ \\
\hline $\begin{array}{ll}\text { Guide } \quad \text { and } & \text { Van } \\
\text { Wassenhove (2009) } & \end{array}$ & $\begin{array}{l}\text { GSCM is about recovering values from reuse and } \\
\text { recycling. These objectives result in the formation of } \\
\text { a closed loop supply chain network design. }\end{array}$ \\
\hline Ali and Govindan (2011) & $\begin{array}{l}\text { GSCM is defined as an organizational philosophy to } \\
\text { reduce environmental risks. }\end{array}$ \\
\hline $\begin{array}{l}\text { Gunasekaran } \\
\text { Spalanzani (2012) }\end{array}$ & $\begin{array}{l}\text { GSCM is an organizational philosophy which } \\
\text { provides competitive edge to an organization. }\end{array}$ \\
\hline Schrettle et al. (2014) & $\begin{array}{l}\text { GSCM is a tool which helps to position company } \\
\text { from a strategic perspective. }\end{array}$ \\
\hline
\end{tabular}


It is quite clear from the above definitions that GSCM is an organizational philosophy which integrates environmental dimensions with the traditional supply chain network, which includes procurement, logistics, manufacturing, distribution and disposal or reuse/recycling. Vonderembse et al. (2006) suggested that different supply chain strategies are pursued in different product life cycle phases. Further, there are four types of product, i.e. standard, innovative, hybrid and green. In the case of green products, a hybrid supply chain design with an environmental focus is the most appropriate strategy.

Successful implementation of GSCM and its integration with corporate strategy requires leadership, building organizational culture, supply chain collaboration (i.e. involving suppliers, transporters and customers) and regulatory norms. In other words, it can be termed as a strategy to improve sustainability and improve organizational performance. According to Srivastava (2007) and Lu et al. (2007), GSCM has evolved as a result of natural resource depletion and environmental degradation. Over the last two decades, pollution has exceeded safe levels, threatening dire consequences. Hence on the basis of extensive review of existing GSCM definitions we have proposed our operational definition as, ".... The green supply chain management (GSCM) is an organization philosophy which can provide competitive advantage to the organization in terms of high product quality, high service quality, minimum wastes, zero pollution, better image, and high return on investment...".

\section{Research methodology}

In an attempt to answer the research question RQ2 and to further help us to address question RQ3, we use a literature review approach. Past researchers have used a literature review to identify the constructs within a particular research framework and identify relevant theories (e.g. Srivastava, 2007; 
Baines et al., 2012; Gunasekaran and Spalanzani, 2012; Muduli and Barve, 2013; Gaussin et al., 2013).

Our study aims to develop a theoretical framework that will contribute to existing theories of GSCM based on a survey of extant literature and grey literature, and further to identify future research directions. We have found that older review-based research did not adopt the systematic literature review methodology. We observed in our review that systematic literature review (SLR) is a trend that researchers have adopted in more recent papers (e.g. Pittaway et al., 2004; Van Aken, 2005; Lightfoot et al., 2013) in order to synthesize and organize research findings from multiple studies in an orderly and transparent manner. In our research process, we have adhered to the principles that are integral to SLR, i.e. that it must be transparent, replicable and rational. The review process undertaken by $u$ is presented in Figure 1, adapted from Lightfoot et al. (2013). We have systematically identified scholarly works from databases like Science Direct, Compendex, Ebsco, Emerald and Scopus, and the justification for this selection is provided briefly below.

Science Direct is one of the leading databases in terms of number of journals concerned with supply chain management and the related area of operations management. Journals include International Journal of Production Economics, Journal of Cleaner Production, Omega, Journal of Operations Management, Transportation Research (Parts A, B, C and D), European Journal of Operational Research, Journal of Purchasing and Supply Management and Resources, Conservations and Recycling. Emerald is a popular database that publishes reputable journals in the field of operations and supply chain management including International Journal of Operations and Production Management, Supply Chain Management: An International Journal, International Journal of Physical Distribution and Logistics Management and International Journal of Logistics Management. Beside these journals, we looked at other reputable journals which are highly reputable in their fields, including MIT Sloan Review, Journal of Supply Chain Management, Transportation Journal, 
Journal of Business Logistics, International Journal of Production Research, Production, Planning and Control, International Journal of Logistics Research and Applications, International Journal of Procurement Management, and International Journal of Services and Operations Management and other journals, depending upon the suitability of the articles. Our search was based on broad-based terms and strings associated with the field of green supply chain, GSCM practices and theories of GSCM, green manufacturing, green procurement, green logistics and carbon footprints. In order to assure ourselves that we were not missing any relevant work(s), we explored the same search strings further in Google Scholar. This process identified 323 apparently relevant articles as a basis for further analysis. To narrow our analysis, we read the abstracts and key words of the initial selection to further limit ourselves to 248 relevant articles. Once the inclusion and exclusion choices had been made, the cross-checking of authors and references and, where possible, consultation with scientific communities producing interim/unpublished relevant work (grey literature) further informed and increased the pool to 262 published principal articles. All articles were considered to be representative of the current body of knowledge associated with GSCM, GSCM practices and theories of GSCM.

We have characterised the various stages of the systematic review as follows: Identification of review

We have identified our areas based on our research questions, following which we were able to identify our journals and grey literature.

Electronic search in databases

This includes popular databases in the field of operations management and related fields such as logistics management, supply chain management, transportation, and environmental management. The databases discussed above contain a rich and diversified repository of reputable journal articles. However, it must also be acknowledged that these databases have their own limitations. First, the databases do not include technical reports. Second, there are many journals which are not indexed. In such a situation, sources in the 
open access domain, such as Google scholar, where all grey literature is available, provide great support.

Title and abstract review

This involves simply reading titles and related abstracts to draw insights into the suitability of the articles. Therefore, researchers can rapidly eliminate those articles which are not relevant to the research. In this way, we identified 323 papers relevant to our research questions.

Apply inclusion and exclusion principles

This helped us to further concentrate on the 248 articles that we have included in our present research. This is done by including reference checks and grey literatures.

Create data extraction excel files

This is a structured documentation process which has helped to define GSCM and its related practices, recent trends in GSCM and sustainability areas, research gaps, and further scope for research.

Descriptive and thematic analyses

The thematic analysis involved a detailed review of the content of each research article. To do this we created a coding frame to catalogue the textual content and brief summaries of each paper. 
Identification of Review

Stage 2

Electronic search in databases ( Scopus, Emerald, Science Direct etc.) using key words like GSCM, Green Supply Chain Management, and Green Supply Chain

Stage3

Title and abstract reviews of identified papers (323 articles)

Stage 4

Apply inclusion and exclusion criteria

Stage 5

Papers selected for review (248 articles)

\section{Stage 6}

Create data extraction files

\section{Stage 7}

Descriptive and schematic analyses

\section{Stage 8}

Reporting (see section 4)

\section{Figure 1: Review Procedure}

(Adapted from Malviya and Kant, 2015 and further refined as per our study needs)

We have classified current literature into various categories like GSCM practices, critical success factors (CSFs) along the supply chain network, and theories of GSCM. This is our attempt to answer research question RQ1 which we posited in the introduction section - which will be further synthesized to build a conceptual framework of GSCM which will provide an answer to our research question RQ3. This is the main contribution of our 
present paper. Finally, as a part of our research contribution, we present the performance measures and metrics.

\section{Classification scheme for the literature on GSCM}

We have classified our literature into three sections. In the first section we have presented bibliometrics study of the GSCM articles on the basis of yearwise, country-wise and study-wise. Second we have attempted to classify literature on the basis of organizational theories following Ketchen and Hult (2007) and Sarkis et al. (2011) suggestions. Third, we have discussed generic concerns related to GSCM literature. Fourth, we have classified literature on the basis of building blocks of GSCM framework and finally we have presented our GSCM framework and its performance measures.

\subsection{Bibliometrics Study of GSCM articles}

Malviya and Kant (2015) have made an attempt to classify the GSCM literature on the basis of year-wise publications, country-wise, affiliationswise, publishing house-wise, research-design wise and techniques-wise. Hence we have only restricted our attempt to year-wise, country-wise and research methods to avoid any duplication.

\subsubsection{GSCM studies according to the year of the articles published}

We have used Scopus database to classify the GSCM literature following QS World University Rankings (2015) suggestions. The Table 2, which indicates that number of articles, published surrounding GSCM in Scopus indexed Journals have increased exponentially from year 1990 to year 2014. However it is noted that number of article published in the year 2015 is slightly lower than the year 2014 which is due to shift in the focus of the authors from GSCM to SSCM field which is considered to be more holistic than GSCM field. However our current focus is on GSCM related study, hence we have only presented detailed longitudinal analysis of articles published from year 1990 till year 2016 (April). 
Table 2: Longitudinal analysis of GSCM literature

\begin{tabular}{|c|c|}
\hline+2 & Number of articles published \\
\hline 20 & $62 *$ \\
\hline 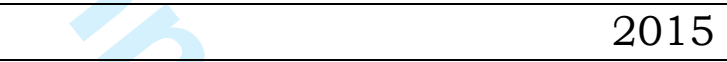 & 211 \\
\hline 20 & 251 \\
\hline 80 & 216 \\
\hline 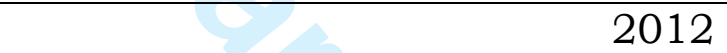 & 156 \\
\hline 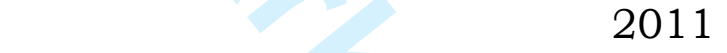 & 162 \\
\hline 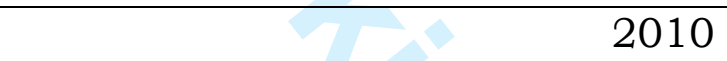 & 150 \\
\hline 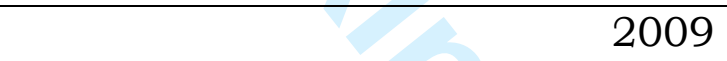 & 93 \\
\hline 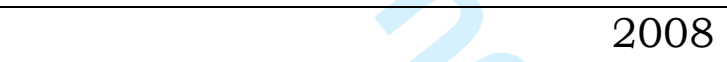 & 70 \\
\hline 2007 & 39 \\
\hline 2006 & 31 \\
\hline 2005 & 22 \\
\hline 2004 & 13 \\
\hline 2003 & 10 \\
\hline 2002 & 11 \\
\hline 2001 & P \\
\hline 2000 & 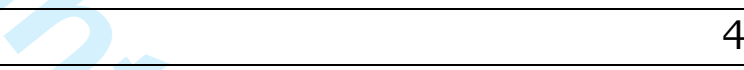 \\
\hline 1999 & 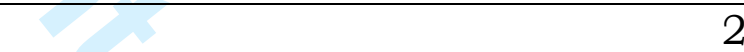 \\
\hline 1998 & $+(0)$ \\
\hline 1997 & $-2 / 3$ \\
\hline 1996 & 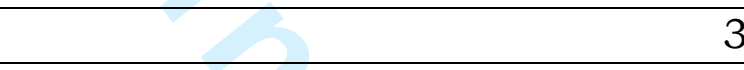 \\
\hline 1995 & $2=$ \\
\hline 1994 & 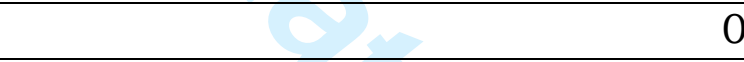 \\
\hline 1993 & $x^{2}$ \\
\hline 1992 & $P_{2}$ \\
\hline 1991 & 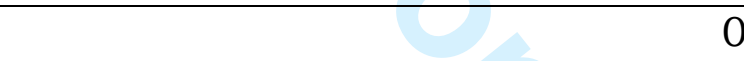 \\
\hline 1990 & 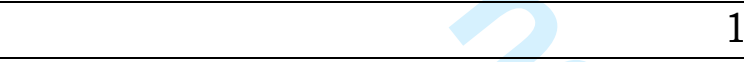 \\
\hline
\end{tabular}

(Source: Date of access 14th April, 2016 using Scopus database)

(* represent that the articles included till April) 
The Table 2 clearly reflects increasing trends towards GSCM related research which has gained significant attentions among researchers from year 2008. Hence the field is still in nascent stage and requires significant attentions to take the current research to next level.

\subsubsection{GSCM studies classification on the basis country-wise}

In this study we attempted to understand contribution towards GSCM literature on the basis of country to create awareness among scholars to understand how the researchers affiliated to the Universities or institutions located in these countries or territories. We have used Scopus database followed by "green supply chain management" key word to identify literature. We have already submitted that Scopus database may not cover all the literature. The majority of the researchers agree that Scopus database includes that literature published after several rounds of revision. In the Table 3 we have dropped those countries whose contribution is less than 2 so that we can focus on those countries whose authors have contributed significantly in Scopus indexed Journals. The Table 3 clearly indicates that China researchers have made significant contributions towards the emerging field. After China, the US researchers have made significant contributions followed United Kingdom, Taiwan and India. Hence there is tremendous opportunity in the field of GSCM as more than 90 percent of the countries researchers have not yet explored the opportunities in the field.

Table 3: Countries wise distribution of the GSCM articles

\begin{tabular}{|r|r|}
\hline Countries & Number of articles published \\
\hline China & 343 \\
\hline United States & 47 \\
\hline Hong Kong (Special Administrative & 16 \\
\hline Region) & 10 \\
\hline United Kingdom & 9 \\
\hline Taiwan & 7 \\
\hline India & 6 \\
\hline
\end{tabular}


(Source: Date of access 14th April, 2016 using Scopus database)

The number of the articles published may be higher as most of the articles which are published are yet to be reflected. In such case Brazil, Finland, Canada, France and other countries may be included. The countries like Brazil, France, Russia and Germany have published their articles in their language. Hence due to lack of awareness towards English Journals, the most of the published articles may not be included in leading indexing databases. Thus the Table 3 may only represent partial reality.

\subsubsection{Research Methods}

We have analyzed each article of GSCM and we have noted down the research methods. The major research articles focus on the methods like survey, mathematical modelling, simulation, case studies and conceptual models. We have classified 248 papers on the basis of research methods are shown in Table 4.

Table 4: Research Methods applied for GSCM

\begin{tabular}{|l|r|r|}
\hline & Number of articles & \multicolumn{1}{l|}{} \\
\hline Survey & 112 & 45.16 \\
\hline Mathematical Modelling & 67 & 27.02 \\
\hline Conceptual Model & 21 & 8.47 \\
\hline Qualitative Methods & 48 & 19.35 \\
\hline Total & 248 & 100.00 \\
\hline
\end{tabular}

However we can see that survey based articles represent $45.16 \%$ of the 248 articles which represent significant contributions. However most of the survey based articles lack enough guiding theories and secondly most of the articles lack enough scientific rigors. Hence in recent years some of the Journals like Journal of Operations Management, Journal of Supply Chain Management, Journal of Business Logistics, International Journal of Production Economics, 
International Journal of Logistics Management and International Journal of Operations and Production Management have clearly outlined in their editorial note that those articles which does not meet scientific rigors may be desk rejected. Finally we have noted that articles using triangulation approach are limited and hence this may be one of the areas which require significant attentions (see Fawcett et al. 2014).

\subsection{GSCM theories}

Currently, there exists a gap in the available literature in the area of GSCM studies relating to providing theoretical support to explain the existence and the boundaries of green supply chain management. A few authors (such as Rosen et al., 2002; Maignan and McAlistar, 2003; Zhu and Sarkis, 2004; Rao and Holt, 2005; Vachon and Klassen, 2006; Zhu and Sarkis, 2007; Carter and Rogers, 2008; Delmas and Montiel, 2009; Sarkis et al., 2011; Zhu et al., 2012; Shi et al., 2012; Schrettle et al., 2014) have tried make use of organizational theories to provide theoretical foundations for different areas related to the supply chain. These theories include:

- Complexity theory (CT)

- Resource-based view (RBV)

- Transaction cost analysis (TCA)

- Knowledge based view (KBV)

- Strategic choice theory (SCT)

- Agency theory (AT)

- Institutional theory (InT)

- Systems theory (ST)

- Network perspective (NP)

- Ecological modernization theory (EMT)

- Information theory (IT)

- Resource dependent theory (RDT)

- Social network theory (SNT).

We have categorized GSCM literature into 13 theories, as shown in Table 5. 
Table 5: GSCM theories

\begin{tabular}{|c|c|}
\hline Theory & References \\
\hline Complexity Theory (CT) & $\begin{array}{l}\text { Vachon and Klassen (2006); Choi and Krause } \\
\text { (2006); Matos and Hall (2007); Guide and Van } \\
\text { Wassenhove (2009); Sarkis et al., 2011; } \\
\text { Gunasekaran et al., 2014; Govindan et al, } \\
\text { 2014. }\end{array}$ \\
\hline Resource Based View (RBV) & $\begin{array}{l}\text { Rao and Holt, 2005; Zhu and Sarkis, 2006; } \\
\text { Vachon and Klassen, 2007; Gold et al., 2010; } \\
\text { Sarkis et al., 2010; Sarkis et al., 2011; Shi et al., } \\
\text { 2012. }\end{array}$ \\
\hline $\begin{array}{l}\text { Transaction Cost Analysis } \\
\text { (TCA) }\end{array}$ & $\begin{array}{l}\text { Rosen et al., 2002; Sheu et al., 2005; Yang et } \\
\text { al., 2010; Delmas and Montiel, 2009; Chen et } \\
\text { al., 2012; Barari et al., 2012; Chaabane et al., } \\
\text { 2012; Caniels et al., 2013. }\end{array}$ \\
\hline $\begin{array}{lll}\begin{array}{l}\text { Knowledge } \\
\text { (KBV) }\end{array} & \text { Based } & \text { View } \\
\end{array}$ & Sheu and Chen, 2012; Schrettle et al., 2014. \\
\hline $\begin{array}{l}\text { Strategic } \text { Choice } \\
\text { (SCT) }\end{array}$ & $\begin{array}{l}\text { Siaminwe et al., 2005; Stone 2006; Brown and } \\
\text { Stone 2007; Berkel 2007; Deif 2011; Despeisse } \\
\text { et al., 2012; Law and Gunasekaran, 2012;Singh } \\
\text { et al.,2012; Dues et al., 2013; Hoof and Lyon } \\
\text { 2013. }\end{array}$ \\
\hline Agency Theory (AT) & $\begin{array}{l}\text { Bierma and Waterstraat 1999; Vachon and } \\
\text { Klassen 2006; Hsu and Hu 2009; Bai and Sarkis } \\
\text { 2010; Ku et al., 2010; Testa and Iraldo 2010; } \\
\text { Hoof and Lyon 2013. }\end{array}$ \\
\hline Institutional Theory (InT) & $\begin{array}{l}\text { Corral, 2003; Zhu et al., 2005; Tsoulfas and } \\
\text { Pappis 2006; Sarkis et al., 2011; Singh et al., } \\
\text { 2012; Zhu et al., 2013; Dubey and Bag, 2013. }\end{array}$ \\
\hline Systems Theory(ST) & Holt and Ghobadian (2009) \\
\hline Network Perspective (NP) & Van Bommel (2011) \\
\hline $\begin{array}{ll}\text { Ecological } & \text { Modernization } \\
\text { Theory (EMT) }\end{array}$ & $\begin{array}{l}\text { Kassolis, 2007; Zhu et al., 2010; Park et al., } \\
\text { 2010; Sarkis et al., } 2011 \text {. }\end{array}$ \\
\hline Information Theory (IT) & $\begin{array}{l}\text { Jiang and Bansal, 2001; Erlandsson and } \\
\text { Tillman, 2009; Sarkis et al., } 2011 .\end{array}$ \\
\hline $\begin{array}{l}\text { Resource Dependent Theory } \\
\text { (RDT) }\end{array}$ & $\begin{array}{l}\text { Zhu and Sarkis, 2004; Zhu et al., 2005; Carter } \\
\text { and Rogers, 2008; Shang et al., } 2010 .\end{array}$ \\
\hline Social Network Theory (SNT) & $\begin{array}{l}\text { Maignan and McAlister, 2003; Seyfang, 2006; } \\
\text { Mollenkopf et al., 2010; Wu et al., } 2012 .\end{array}$ \\
\hline
\end{tabular}


The contributions to the various theories of GSCM over the past decade reflect the growing popularity of the subject. However, there are still very few contributions to Knowledge Based View Theory and Systems Theory. In addition, although GSCM literature has evolved in the past decade, nevertheless, with few exceptions, most of the literature lacks supporting theory. Further, most of the literature contains overlapping theories which reflect a lack of understanding among most of the researchers regarding GSCM theories. On the other hand, SCM literature has demonstrated better understanding in terms of theory. Hence, it can be concluded that GSCM and SSCM areas are relatively new disciplines, and over 70 per cent of the contributions have come from onely 15 per cent of first authors, which reflects the urgent need for contributions from other researchers with a strong understanding of theory and methodology.

\subsection{Generic research concerns with GSCM}

On the basis of our review of the current literature, we have identified a number of research concerns, which will help us to propose our conceptual framework. These are discussed below.

\subsubsection{Lack of proper understanding of GSCM and related research}

We have reviewed articles related to GSCM, and we have found that there are overlaps between these two concepts. However, most of the recent literature focuses on SSCM. In this section we have made an attempt to resolve debates related to GSCM.

We have already discussed in detail GSCM and its definitions based on scholarly works, and we have identified some of the extant literature that explains SSCM more comprehensively. SSCM embraces not only environmental performance measures along with the profit/loss statement; it also includes social performance measures (e.g. Linton et al., 2007; Carter and Rogers, 2008). 
However, in the past the GSCM literature has focused primarily on the impacts of GSCM practices on environmental and financial performance. However, except for a few notable contributions (e.g. Carter and Easton, 2011; Ameer and Otham, 2012; Zailani et al., 2012; Hoejmose and Adrien-Kirby, 2012; Wang and Sarkis, 2013), there is a dearth of literature which has reflected on social dimensions.

It can be concluded that the social dimension area needs to be further explored. However, at present we can hardly differentiate between GSCM and SSCM practices. SSCM practices and their impact on social performance need to be further explored, which will further strengthen the claims of past scholars.

This limitation could be attributed to methodology issues. In the past, major empirical research has almost exclusively employed perceptual performance measures (with the notable exception of Wang and Sarkis, 2013). Such perceptual performance measures cannot provide a comprehensive picture of the situation. Hence, it has been suggested that financial data may be used in addition. In recent years researchers have expressed their concerns regarding the availability of financial data to validate a theoretical framework. In addition, researchers have in the past collected data in a single time period. Consequently, causality cannot be established without longitudinal data.

\subsubsection{Decoding the missing link in GSCM theories}

We have classified the literature into thirteen GSCM theories (see Table 2), through which we have attempted to extend the recent notable contribution of Sarkis et al. (2011), in which the authors classified the literature into nine organizational theories.

We can conclude from Table 5 that there are valuable contributions to Institutional Theory (InT), Resource Based Theory (RBT) and Transaction Cost Analysis theory (TCA); however, there are few contributions which have made any significant contribution to Knowledge Based Theory (KBT), Systems Theory 
(ST) or Network Perspective theory (NP). Before we proceed further, it is useful to review our understanding of RBT, ST and NP.

$\boldsymbol{K B T}$ : According to KBT, the knowledge within the firm is regarded as its most strategically significant resource, providing competitive advantage for any firm. There is an argument that knowledge is something that is socially complex and difficult for competitors to imitate (Grant, 1996). KBT is an extension of RBT theory proposed by a number of authors (Wernerfelt, 1984; Barney, 1991; Conner, 1991). Similarly, the Green Intellectual Capital (GIC) of a firm comprises the sum of all its green knowledge (Claver-Cortes, 2007). Chen (2008) defined GIC as an inventory of intangible assets, knowledge, capabilities, relationships etc. concerning environmental protection. GIC has further been classified into human capital, green structural capital and green relational capital (e.g. Lopez-Gamero et al., 2010).

However, we have not come across any framework which has explored the knowledge dimensions of the firm and their impacts on organizational performance. Consequently, we can conclude that knowledge is the missing link in the present GSCM literature, which creates a platform for future research directions.

ST:Systems theory (ST) includes components like input (I), output (O), process $(\mathrm{P})$, environment $(\mathrm{E})$, agent $(\mathrm{A})$, mechanism $(\mathrm{M})$ and function (Chandra and Tumanyan, 2005). Holt and Ghobadian (2009) argued in one of their articles that GSCM research is in an embryonic phase and major contributions are required either towards the upstream end, i.e. focusing more towards green purchasing, or the downstream end, i.e. focusing more towards physical distribution. However, except in a few cases, most of the research on GSCM lacks a holistic view.

Holt and Ghobadian (2009) have tried to contribute to Systems Theory (ST) by supplying the missing link in the GSCM literature. However, excepting this single piece of work, there are hardly any notable contributions to the field of Systems Theory. This gap can further be explored in future research. 


\subsubsection{Supply chain complexity and product complexity}

In the past, supply chain complexity has received widespread attention from researchers (Choi et al., 2001; Choi and Krause, 2006; Bozarth et al., 2009; Jacobs, 2013). Previously, supply chain complexity has been treated as a multi-dimensional construct (Choi and Krause, 2006; Closs et al., 2008; Bozarth et al., 2009; Closs et al., 2010; Jacobs and Swink, 2011). Extending previous research (e.g. Vachon and Klassen, 2002; Bozarth et al., 2009), we view supply chain complexity as it relates to the GSCM network, which is the missing link in current GSCM literature.

Second, we further consider product complexity, which stems from the customization, intricacy and variety of the firm's products (Schoenherr et al., 2010). Past research has shown a negative impact of product complexity on supply chain performance (e.g. Fisher et al., 1999; Krishnan and Gupta, 2001; Ramdas and Sawhney, 2001; Salvador et al., 2002; Hu et al., 2008). However, it has also been linked to sales growth (Lancaster, 1979; Kekre and Srinivasan, 1990; Quelch and Kenny, 1994), implying a trade-off for managers between sales growth through added product complexity and enhanced operational efficiency through product rationalization (Salvador et al., 2002). Some researchers have similarly suggested that product complexity may not result in negative performance effects (Bozarth et al., 2009; Blome et al., 2013). To the best of our knowledge, no studies have been conducted on the impact of product complexity on the green supply chain network.

\subsubsection{Methodological issues}

In recent years there has been growing evidence of the use of graph theory. Graph theory matrix application techniques have been used extensively to resolve inherent complexities among variables of GSCM, where there are limitations in the use of multivariate statistics (e.g. Luthra et al., 2011; Mangla et al., 2013; Mathiyazhagan et al., 2013; Muduli et al., 2013; Jabbour et al., 2013) or the use of multiple criteria decision making techniques (e.g. Wang et al., 2012; Govindan et al., 2014; Brandenburg et al., 2014). However, there is a 
dearth of articles which have have integrated two diverse methodologies, e.g. graph theory and statistical techniques, to create reinforcement.

\subsection{Conceptual Framework and Research Propositions}

The foundation of our theoretical framework comprises of two elements: systems theory and the influence of knowledge based view theory on GSCM network (see Figure 1). During last one decade the the knowledge based theory(KBT) in recent years (e.g. Sheu and Chen, 2012; Schrettle et al., 2014) has attracted attention in context to GSCM field. We argue that systems theory approach with integration with knowledge based view theory can provide a better insight which systems theory or knowledge based view theory in isolation cannot provide. In this case green intellectual capital (GIC) of any organization can certainly provide an effective outcome. However, we cannot exclude the possibility of others factors which includes environmental uncertainty, product complexity and confounding variables (i.e. environmental uncertainty, organizational size, etc.) may influence our proposed framework, a possibility that will be considered in our proposed conceptual framework. The Conceptual framework is a precursor to hypothesis generation. The some of the features that includes are identification of relevant variables, discussions of relationships among variables, indications of nature and direction of relationship and development of a schematic diagram of the framework. We have followed some of the assumptions for building conceptual framework that are necessary for evolving hypotheses.

- The variables which are outlined are relevant to study and labeled in the discussions;

- The discussions has identified the nature of the linkage among the variables;

- We have theorized the nature and relationship among variables based on existing GSCM theories based on findings from extant literature; 
- We have provided clear explanations and literature support, to justify the nature of linkage;

- A schematic diagram of the conceptual framework, which we have presented so that one can clearly visualize the theorized relationships.

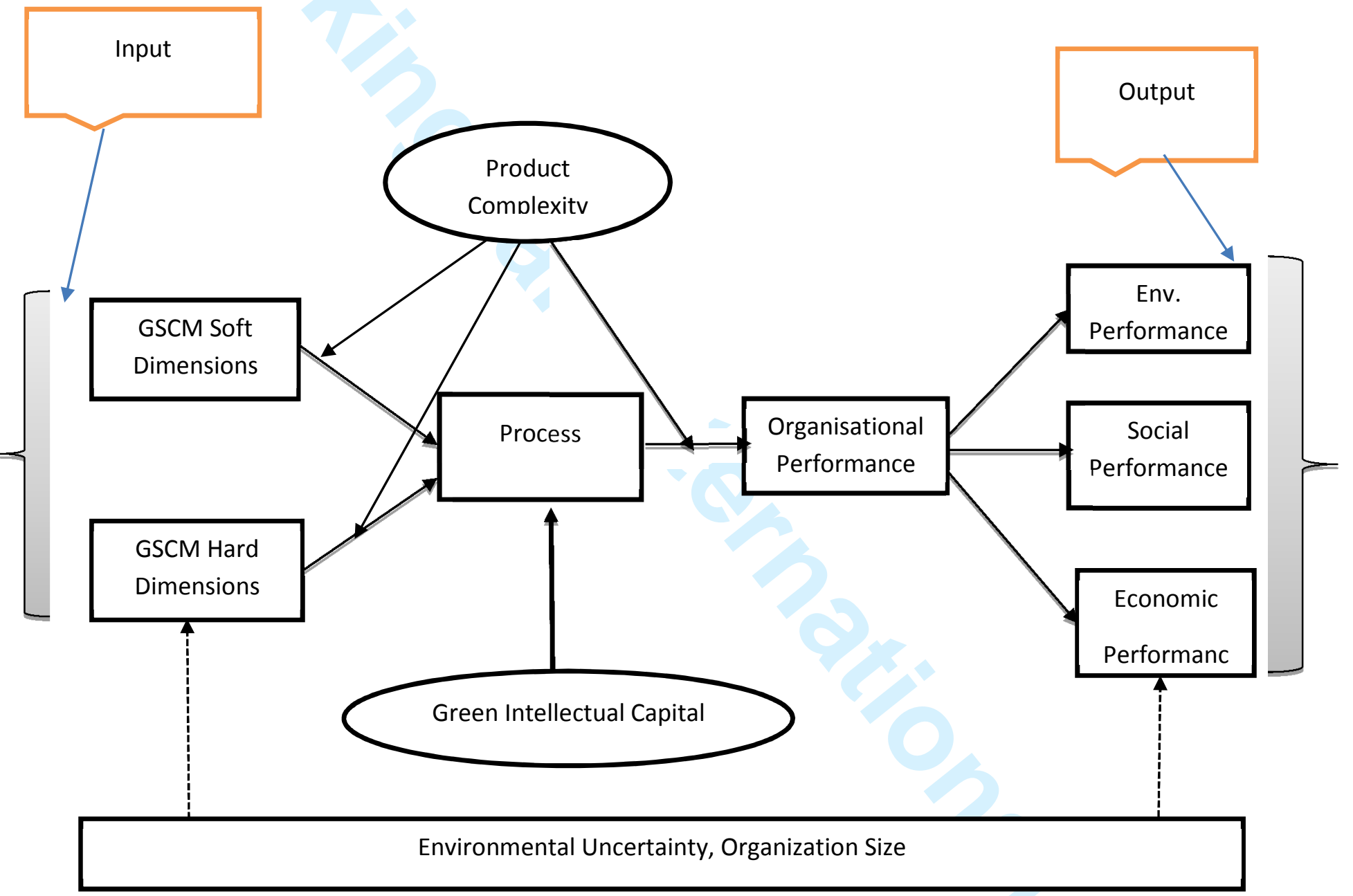

Figure 1: Conceptual Framework 
In this section we have made an attempt to classify our literature based on building blocks of our conceptual framework for GSCM as shown in Figure 2. We have adopted system components approach to define our conceptual framework for GSCM (Chandra and Tunmanyan, 2005; Holt and Ghobadian, 2009).

The system components are:

- Input;

- Process;

- Output;

- Environment;

- Function

\subsubsection{Input}

It refers to GSCM CSFs, which have classified into two categories:

- GSCM soft dimensions;

- GSCM hard dimensions;

\section{GSCM soft dimensions}

It refers to human resource related dimensions. From in depth exhaustive literature review we have seen that soft dimensions have positive impact on GSCM implementation (see Table 6). It includes top management commitment, employee involvement, organizational culture, team work, green motivation, customer relationship and supplier relationship.

\section{GSCM hard dimensions}

It refers to strategy, technology and policy adopted by firm to implement GSCM successfully. We have identified from literature review, that hard dimensions of GSCM has positive influence on GSCM implementation (see Table 6). It includes lean manufacturing, total quality management, technologies for cleaner production, product innovation, green logistics, green purchasing and regulatory norms. 
According to American Society for Quality "Critical success factors allow an organization to assess the success of a project, selection process, or other activities with stated goals...."In other words it is a strategic tool. Based on extensive review we have presented a non-exhaustive list of CSFs as shown in Table 6, which we have further classified into two broad categories. One group of CSFs has its root in production management and another group which its root in human resource management. The first group is referred as hard dimensions of GSCM and another group which is known as soft dimensions of GSCM.

\section{Table 6: Critical Success Factors (CSFs) of GSCM}

\begin{tabular}{|l|l|l|}
\hline $\begin{array}{l}\text { Dimensions } \\
\text { GSCM hard } \\
\text { dimensions }\end{array}$ & CSFs & References \\
\cline { 2 - 3 } & $\begin{array}{l}\text { Total Manufacturing } \\
\text { Management }\end{array}$ & $\begin{array}{l}\text { Farish 2009; Franchetti et al., 2009; } \\
\text { Deif 2011; Dues et al., 2013; Dubey and } \\
\text { Ali, 2015a }\end{array}$ \\
\cline { 2 - 3 } & $\begin{array}{l}\text { Supplier } \\
\text { Relationship } \\
\text { Management } \\
\text { Prajogo et al., 2012; Pereira-Moliner et } \\
\text { al., 2012; Dubey and Ali, 2015a }\end{array}$ \\
\cline { 2 - 3 } & $\begin{array}{l}\text { Bierma and Waterstraat 1999; Vachon } \\
\text { and Klassen 2006; Hsu and Hu 2009; } \\
\text { Bai and Sarkis 2010; Ku et al., 2010; } \\
\text { Testa and Iraldo 2010; van Hoof and } \\
\text { Lyon 2013; Dubey and Ali, 2015a }\end{array}$ \\
\cline { 2 - 3 } & $\begin{array}{l}\text { Technologies foaner } \\
\text { production/green } \\
\text { manufacturing }\end{array}$ & $\begin{array}{l}\text { Sikdar and Howell 1998; Zhang et al., } \\
\text { 2013; van Hoof and Lyon 2013 }\end{array}$ \\
\cline { 2 - 3 } $\begin{array}{l}\text { Institutional } \\
\text { Pressures }\end{array}$ & $\begin{array}{l}\text { Zhu et al., 2005; Tsoulfas and Pappis } \\
\text { 2006;Sarkis et al.,2011; Singh et } \\
\text { al.,2012 }\end{array}$ \\
\cline { 2 - 3 } & Green Logistics & $\begin{array}{l}\text { Zhu et al.,2007;Bjorklund,2011; Singh } \\
\text { et al., 2012 }\end{array}$ \\
\cline { 2 - 3 } & Green Purchasing \\
& $\begin{array}{l}\text { Narasimhan and Carter,1998;Carter et } \\
\text { al.1998;Gilbert,2000;Zhu } \\
\text { al.,2007;Bjorklund ,2011; Singh et } \\
\text { al.,2012;Blome et al.,2014 } \\
\text { Olugu et al.,2011;Muduli et al.,2013 }\end{array}$ \\
\hline
\end{tabular}




\begin{tabular}{|c|c|c|}
\hline $\begin{array}{l}\text { GSCM soft } \\
\text { dimensions }\end{array}$ & $\begin{array}{l}\text { Top management } \\
\text { commitment }\end{array}$ & $\begin{array}{l}\text { Siaminwe et al., 2005; Stone 2006; } \\
\text { Brown and Stone 2007; Berkel 2007; } \\
\text { Deif 2011; Despeisse et al., 2012; Law } \\
\text { and Gunasekaran, 2012;Singh et } \\
\text { al.,2012; Dues et al., 2013; van Hoof } \\
\text { and Lyon } 2013\end{array}$ \\
\hline & $\begin{array}{l}\text { Employee } \\
\text { involvement }\end{array}$ & $\begin{array}{l}\text { Atlas and Florida,1998; Chien and } \\
\text { Shih,2007;Hsu et al.,2008;Luthra et } \\
\text { al.,2011 }\end{array}$ \\
\hline & $\begin{array}{l}\text { Customer } \\
\text { Relationship } \\
\text { Management }\end{array}$ & Seuring et al.,2007;Baines et al.,2012 \\
\hline & $\begin{array}{l}\text { Organizational } \\
\text { culture }\end{array}$ & $\begin{array}{l}\text { Fernandez et al.,2003;Govindarajulu } \\
\text { and Daily,2004;Jabbour r and } \\
\text { Santos,2008 }\end{array}$ \\
\hline & Team work & $\begin{array}{lr}\text { Kaitazawa and Sarkis,2000;Daily } & \text { and } \\
\text { Huang,2001;Govindarajulu } & \text { and } \\
\text { Daily,2004;Jabbour } & \text { and } \\
\text { Santos,2008;Massoud } & \text { et } \\
\text { al.,2011;Muduli et al.,2013 } & \end{array}$ \\
\hline & Green motivation & Wee and Quazi,2005; Muduli et al.,2013 \\
\hline
\end{tabular}

\subsubsection{Process}

In this we have considered five major activities along supply chain network. It includes procurement, inbound logistics, manufacturing, outbound logistics and reverse logistics.

\section{Green procurement}

It is defined as aligning environmental policies, with the traditional procurement process. Green procurement emphasizes on reduction of waste produced, material substitution through environmental sourcing of raw materials, waste minimization of hazardous materials and so on (Dubey et al.,2013). The involvement and support of suppliers' is crucial to achieving such goals. The contributions which shows positive linkage between green procurement and superior organizational performance (e.g. Zsidin and Siferd,2000;Carter et.2000;Walker and Philips,2000;Bala et 
al.,2008;Salam,2008;Dada et al.,2010;Tripathi and Petro,2010;Yen and Yen,2011;Gavronski et al.,2011;Dubey et al.,2013).

\section{Green logistics (Inbound and Outbound logistics)}

Transportation and warehousing are two important activities of logistics. The transportation is one of the major contributors of pollution. In order to achieve sustainability, greening of transport is one of the major challenges in front of transportation companies or 3PL service providers(e.g.Mahler,2007;Turner and Houston,2009;Hopkins,2009;Berns et al.,2009;Golicic et al.,2010;UNEP,2011;Blanco and Cottrill,2013).In recent years green logistics has attracted interest among academia (e.g. Marin and Pelegrin 1998, Jayaraman et al., 1999, Fleischmanin et al., 2001, Krikke et al., 2003, Lu and Bostel 2007, Ko and Evans 2007, Min and Ko 2008, Lee and Dong 2008, Easwaran and Uster 2009, Wang and Hsu 2010, Zarei et al., 2010, Easwaran and Uster 2010;Sundarakani et al.,2010;Scipioni et al.,2012).

We can define green logistics can be thought of as an approach for planning freight logistics systems that incorporates sustainability goals with a primary focus on the reduction of environmental externalities (Sathaye et al.,2006).Rodrigue et al.,2001 argued in their work that lack of proper understanding among practitioners, result into un resolved conflict. These conflicts are presented as "green logistics paradoxes" in the Table 7.

Table 7: Paradoxes of green logistics

\begin{tabular}{|l|l|l|}
\hline \multicolumn{1}{|c|}{ Dimension } & \multicolumn{1}{|c|}{ Outcome } & \multicolumn{1}{c|}{ Paradox } \\
\hline Costs & Reduction in costs & Environmental costs are \\
through packaging and & often externalized. \\
& reduction of wastes. \\
& Benefits are derived by \\
& the distributors. & \\
\hline
\end{tabular}




\begin{tabular}{|c|c|c|}
\hline Time/Flexibility & $\begin{array}{l}\text { Integrated supply } \\
\text { chains, JIT and Door-to- } \\
\text { Door often provide } \\
\text { flexibility and efficient } \\
\text { physical distribution } \\
\text { systems. }\end{array}$ & $\begin{array}{l}\text { Extended production, } \\
\text { distribution and retailing } \\
\text { often produces more } \\
\text { carbon footprints, } \\
\text { occupy more space and } \\
\text { consumes more energy. }\end{array}$ \\
\hline Network & $\begin{array}{l}\text { Increasing system wide } \\
\text { efficiency through hub \& } \\
\text { spoke distribution. }\end{array}$ & $\begin{array}{l}\text { Concentration of } \\
\text { pollution along the hub } \\
\text { and corridors. Pressure } \\
\text { on local communities. }\end{array}$ \\
\hline Reliability & $\begin{array}{l}\text { Reliable and on-time } \\
\text { distribution of freight } \\
\text { and passengers. }\end{array}$ & $\begin{array}{l}\text { Air and Road modes of } \\
\text { transportation are more } \\
\text { threat to environment. }\end{array}$ \\
\hline Warehousing & $\begin{array}{l}\text { Reducing the needs for } \\
\text { private warehousing. }\end{array}$ & $\begin{array}{l}\text { Inventory in part shifting } \\
\text { to roads often leads to } \\
\text { congestion and traffic } \\
\text { abnormalities. }\end{array}$ \\
\hline E-commerce & $\begin{array}{l}\text { Increased business } \\
\text { opportunities } \\
\text { diversification of supply } \\
\text { chains. }\end{array}$ & $\begin{array}{l}\text { Changes in physical } \\
\text { distribution systems } \\
\text { towards higher levels of } \\
\text { energy consumptions. }\end{array}$ \\
\hline
\end{tabular}

\section{Green manufacturing}

The green manufacturing has attracted serious attentions from academia and practitioners in recent years. There are lot of initiatives from corporate houses like IKEA, McDonalds, Sony, Godrej \& Boyce, Bharat Forge,DuPont,IBM etc. which is a non-exhaustive list of companies who have imbibed green production or manufacturing in their corporate strategy(Baines et al.,2012;CII-BCG Report,2013).We have reviewed some of the extant literature like(e.g.Melnyk and Smith,1996; Polcari,2007;Sutor,2007;Baines et 
al.,2012;Gunasekaran and Spalanzani,2012), we can conclude that, "green manufacturing is a collection of activities that involves conversion of inputs into desired product, such that emissions of hazardous substances which are harmful to human health and environment are minimized without compromising with product quality in an economical way.

The dimensions of green manufacturing are:

- Green products(e.g.Kleiner,1991;Hart,1995;Hart,1997;Ginsberg and Bloom,2004;Baines et al.,2012);

- Green processes and operations (Porter and van der Linde, 1995;Ball et al.,2009;Kabir and Madugu,2010;Wernet et al.,2010;Mukherjee,2010;Gunasekaran and Spalanzani,2012).

Reverse logistics

Srivastava (2007), which is one of the most cited literature, has presented a comprehensive view of GSCM, with special focus on reverse logistics (RL).Govindan et al.,(2012), developed a framework for determining carbon footprints in a reverse logistic model. Based on seminal works (e.g.TibbenLembke, 2002; GuideJr. and van Wassenhove, 2003), we have identified two key dimensions for design of $\mathrm{RL}$ are product life cycle and variability of product returns.

The RL is a process that further safeguards natural resources and protect the environment (e.g.Kumar and Putnam,2008;Houe and Grabot,2009;Gunasekaran and Spalanzani,2012). The researchers in recent years have proposed sustainable closed loop supply chain network design (SCLSC), which focuses on dual objectives i.e. reduction of cost and reduction of carbon footprints (e.g.Wang et al.,2011; Chaabane et al.2012). Seuring (2013) and Brandenburg et al.,(2014), have carried out comprehensive reviews on various mathematical models used for building sustainable supply chain model which includes RL and CLSC network design. 
We there for consider RL as an important process and how the soft GSCM and hard GSCM dimensions can influence RL performance, is the missing link in current literature, which we have reviewed. We have further categorized literature into six key practices as we have discussed in Table 8 as:

\section{Table 8: GSCM practices}

\begin{tabular}{|c|c|}
\hline GSCM practice & References \\
\hline $\begin{array}{l}\text { Green } \\
\text { procurement }\end{array}$ & $\begin{array}{ll}\text { Min and Galle,1997;Carter et al.,2000;Zsidisin } & \text { and } \\
\text { Siferd,2001;Vachon,2007;Zhu et al.,2008;Stefan } & \text { and } \\
\text { Paul,2008;Bala et al.,2008;Salam,2008;Holt } & \text { and } \\
\text { Ghobadian,2009;Paulraj,2009;Tripathi } & \text { and } \\
\text { Petro,2010;Bjorklund,2011;Yen and Yen,2011;Large and } \\
\text { Giminez Thomsen,2011;Azevedo et al.,2011;Gavronski et } \\
\text { al.,2011;Routroy and Pradhan,2012;Dubey et al.,2013. }\end{array}$ \\
\hline $\begin{array}{l}\text { Green inbound } \\
\text { logistics }\end{array}$ & $\begin{array}{l}\text { Mahler,2007;Turner and Houston,2009;Hopkins,2009;Berns } \\
\text { et al.,2009;Golicic et al.,2010;UNEP,2011;Blanco and } \\
\text { Cottrill,2013 }\end{array}$ \\
\hline $\begin{array}{l}\text { Green } \\
\text { manufacturing }\end{array}$ & $\begin{array}{l}\text { Azzone and Nocci,1998;Sutherland et al.2008;Kim et } \\
\text { al.2010;Narula and Upadhyay,2011;Zailani et al.,2012;Daily et } \\
\text { al.,2012;Wong et al.,2012;Choi and Chui,2012;Digalwar et } \\
\text { al.,2013;Nouira and Frein,2014;Chen et al.,2014;Golini et } \\
\text { al.,2014. }\end{array}$ \\
\hline $\begin{array}{l}\text { Green outbound } \\
\text { logistics }\end{array}$ & $\begin{array}{l}\text { Murphy et al.1994;Murphy et al.1995;Murphy } \text { and } \\
\text { Poist,2000;Rao and Holt,2005;Zhu et al.,2008;Holt and } \\
\text { Ghobadian,2009;Routroy,2009; UNEP,2011;Blanco }\end{array}$ \\
\hline Reverse logistics & $\begin{array}{l}\text { Carter and Ellram,1998;Lippmann,1999; Rao and Holt } \\
\text {,2005; Hu and Hsu,2006;Zhu et al., 2007;Vachon }\end{array}$ \\
\hline
\end{tabular}


Table 8 present non-exhaustive list of references based on review of literature published in reputable journals, reports and edited books provides an interesting insight. From above list it can be concluded that in last five years, i.e. between 2008 to early 2014, there are over $80 \%$ contribution in the field of GSCM. Second, most of the references are derived from MIT Sloan Review and Supply Chain Management Review along with other reputable academic journals, clearly suggest the popularity of the subject among practitioners and academia. However, most of the studies have focused on impacts of these GSCM practices on environmental performance or financial performance; however there are few concerns related to measurement of social benefits. We will further discuss in detail in our conclusion section where we will provide further research opportunities in the field of GSCM.

Based on extensive discussions we derive following research propositions as:

P1: The soft dimensions of GSCM has postive impact on the process;

P2: The hard dimensions of GSCM has positive impact on the process;

\subsubsection{Output}

In this section we will discuss the impacts of GSCM CSFs on organizational performance. Like any management philosophy, GSCM is also a subject of debate. The growing popularity of the subject has received several criticisms. In various forums and blogs, it has received criticism regarding its feasibility and sustainability. However, under the cover of wide criticisms, the exponential rise in literature published in reputable journals and magazines, that GSCM initiatives adopted by most of the firms has helped firms to improve their performance in terms of financial and non-financial which are critical for the 
sustainable growth of the firms (e.g.Zhu and Sarkis,2004;Zhu et al.,2005;Zhu et al.,2008;Zeng et al.2010;Dues et al.,2013;Dubey and Bag,2013;Yusuf et al.,2013;Schrettle et al.,2014).

An attempt has been made to classify GSCM practices impacts on performance literature, in three broad categories which are determinants of sustainable performance are:

- Economic performance/financial performance;

- Environmental performance;

- Social performance;

The three performance dimensions and their measures are presented in the Table 9.

Table 9: GSCM performance measures

\begin{tabular}{|c|c|c|}
\hline $\begin{array}{l}\text { Performance } \\
\text { measure }\end{array}$ & Item & References \\
\hline \multirow{4}{*}{ 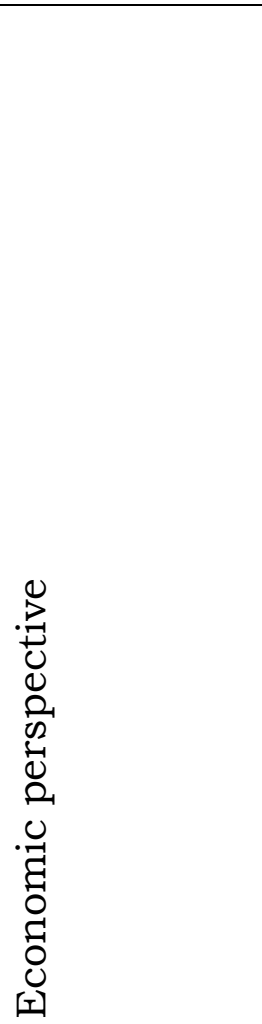 } & Environmental cost & $\begin{array}{l}\text { Hervani et al.,2005;Zhu et } \\
\text { al.,2007;Chardine- Baumann and } \\
\text { Botta-Genoulaz,2011. }\end{array}$ \\
\hline & Supply chain cost & $\begin{array}{l}\text { Olugu et al.,2011; } \\
\text { Baumann } \text { and } \\
\text { Genoulaz,2011; Ageron et al.,2012. }\end{array}$ \\
\hline & Cost to quality & $\begin{array}{l}\text { Hervani et al.,2005;Azevedo et } \\
\text { al.,2011;Chardine- Baumann and } \\
\text { Botta-Genoulaz,2011; Ageron et } \\
\text { al.,2012. }\end{array}$ \\
\hline & Responsiveness cost & $\begin{array}{l}\text { Gunasekaran et al.,2004;Azevedo et } \\
\text { al.,2011;Chardine- Baumann and } \\
\text { Botta-Genoulaz,2011;Ageron et } \\
\text { al.,2012. }\end{array}$ \\
\hline
\end{tabular}




\begin{tabular}{|c|c|c|}
\hline \multirow{4}{*}{ 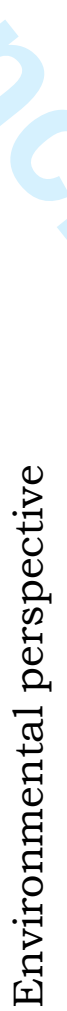 } & $\begin{array}{l}\text { Environmental } \\
\text { technology }\end{array}$ & Azevedo et al.,2011 and Deif,2011. \\
\hline & Recycling efficiency & Hervani et al.,2005; Deif,2011. \\
\hline & Eco packaging & $\begin{array}{l}\text { Hervani et al.,2005; Zhu et al.,2007; } \\
\text { Zhu et al., 2008; Dues et al., 2011; } \\
\text { Kim et al., 2011; Bhateja, et al., } \\
\text { 2012, Seman et al., 2012; Whitelock } \\
2012 \text {. }\end{array}$ \\
\hline & $\begin{array}{lr}\text { Level of } & \text { process } \\
\text { management } & \text { which } \\
\text { includes } \quad \text { pollution } \\
\text { control, } & \text { waste } \\
\text { emissions, } & \text { carbon } \\
\text { footprints etc. } & \end{array}$ & $\begin{array}{l}\text { Hervani et al.,2005; Zhu et al., } \\
\text { 2008; Dues et al., 2011; Kim et al., } \\
\text { 2011; Bhateja, et al., 2012, Seman } \\
\text { et al., 2012; Gangele et al., 2012; } \\
\text { Whitelock 2012. }\end{array}$ \\
\hline \multirow{3}{*}{ 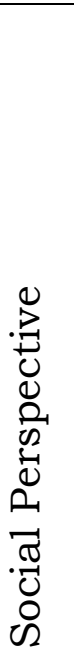 } & $\begin{array}{l}\text { Management } \\
\text { commitment }\end{array}$ & $\begin{array}{l}\text { Hervani et al., 2005; Zhu et al., } \\
\text { 2007; Azevedo et al., 2011. }\end{array}$ \\
\hline & Customer satisfaction & $\begin{array}{l}\text { Zhu et al.,2007;Markley and } \\
\text { Davis,2007;Pocampally et al.,2009; } \\
\text { Gunasekaran } \\
\text { Spalanzani,2012;Dues et al., 2013; } \\
\text { Gavronski et al., 2013. }\end{array}$ \\
\hline & $\begin{array}{l}\text { Employee } \\
\text { development }\end{array}$ & $\begin{array}{l}\text { Markley and } \\
\text { Davis,2007;Pochampally et al.,2009. }\end{array}$ \\
\hline
\end{tabular}

From Table 9 we can conclude that the performance framework reflects triple bottom line (TBL), approach which are now increasingly being adopted by corporates. However, it can be debated on the metrics adopted by researchers to measure social performance. Air pollution is the major factor for the deteriorating health conditions of the human beings. It leads to respiratory infections, heart disease, COPD, stroke and lung cancer. WHO report (2014), 
estimated that 7 million peoples dies due to air pollution. India and China are two countries which has high mortality rate due to air pollution. Hence, the social performance measures must include metrics which measures reduction in mortality rate due to reduction in carbon emissions, decrease in heart disease, decrease pneumonia patients and other pollution related disease. We have not come across any studies have been conducted in GSCM field where mortality rate or decrease in heart patients were considered. Thus, we address this as one of the gap in current GSCM literature.

Based on discussions we can draw our third research proposition:

P3: The process management has positive influence on organisational performance measured in terms of environmental performance, economic performance and social performance;

\subsubsection{Green Intellectual Capital (GIC)}

The GIC is the dimension which can help firm to enhance their competitiveness. The GIC can be regarded as moderating variable (LopezGamero et al.,2010).it has been further classified into three categories as:

- Human capital;

- Green structural capital;

- Green relational capital.

The fourth proposition of our study is:

P4: The GIC has moderating influence on process management;

\subsubsection{Moderating Effects of Product Complexity}

In past supply chain complexity has received significant attention from researchers (e.g. Choi and Krause, 2006; Bozarth et al. 2009). The product complexity can be understood from both product as well from portfolio level (Jacobs, 2013). We argue in our present research that even some research in 
past (e.g. Fisher et al., 1999; Ramdas and Sawhney, 2001; Closs et al., 2010) have found the negative impacts of product complexity on firm performance, product complexity provides the basis for the firm to increase the performance of the organization through proper exploitation of green supply chain network. The supply chain properties in GSCM network can be exploited through principle of modular designs and innovation like postponement strategy (Ethiraj and Levinthal, 2004). Hence our fifth and sixth propositions of our study is:

P5: The product complexity has moderating effect on the influence of soft dimensions on the process management;

P6: The product complexity has moderating effect on the influence of the hard dimensions on the process management;

\subsubsection{Control Variables}

\subsubsection{Environmental Uncertainty}

Chen and Paulraj (2004), regarded uncertainty as an important construct. Davis (1993) suggests that there are three sources of uncertainty which impact supply chain network: supplier uncertainty which arises from on-time performance, average delay, lack of availability of modes of transportation, or delay in plant due to loading; manufacturing uncertainty arising from process performance, machine breakdown, labor strikes etc.; demand uncertainty arising from forecast errors, new product launch, irregular orders etc. In our present study we restrict our discussion to uncertainty in forms of supply, demand and technology. We therefore argue that environmental uncertainty may have confounding effect on impact of soft GSCM factors and hard GSCM factors on entire process in a green supply chain network as shown in Figure 1. To fully account for the differences among organizations, we must control the environmental uncertainty (i.e. uncertainty due to supply, technology and demand). 


\subsubsection{Organizational Size}

In our study we recommend based on extant literature that number of employees and revenue as two measures of organizational size. We argue in our study that bigger size, permits organizations to foster adaption mechanisms such as maintaining shadow systems and slow phasing out of legacy systems. Whereas larger organizations can withstand organizational hurdles by virtue of their size, for smaller organizations survival is more immediate concern. Hence the organization size must be controlled during statistical analysis.

\section{Conclusions, unique contributions and further research directions}

In our present paper we have made an attempt to synthesize current literature from those research communities addressing GSCM/SSCM issues. Our present paper is guided by three research questions as:

RQ1: What are the key constructs of GSCM practices?

In response to question $R Q 1$, we have undertaken systematic literature review of current literature covering GSCM, SCM, sustainable manufacturing, carbon footprints, environment, health \& hazards.

We have made an attempt to define GSCM from various scholars point of view. We have further presented in Table 1.We further classified literature based on specific contribution to GSCM theories. This effort has helped us to further identify recent trends in contribution to specific GSCM theories. We have classified based on contributions into 13 GSCM theories as shown in Table 2.

Once we have identified, GSCM theories we further classified literature based on GSCM factors which are critical for successful implementation of GSCM. We have identified these factors as CSFs based on contributions made by various scholars. We have further classified these CSFs into hard and soft 
dimensions of GSCM, which is our unique contribution to the current GSCM literature.

RQ2: Can we propose a comprehensive framework for GSCM implementation?

This is our main focus of our paper. The aim of proposing a theoretical framework was to address some of the key issue which we have identified through review of current literature. We have structured and aligned our review of literature, in a logical way depicting systems components. We have further classified our literature so that we can classify literature into building block of conceptual GSCM framework. Our building blocks of a GSCM framework are classified into four major components such that each set of variables represent input, process, output and environment of the GSCM framework.

The proposed framework contributes to systems theory and knowledge based view theory. We have further provided metrics for measuring performance of GSCM network. In our framework we have further considered environmental uncertainty and product complexity which were not addressed in past in GSCM literature.

\subsection{Theoretical Contributions}

Whetten (1989), in his seminal work, "What contributes a theoretical contribution?" out of these the most fundamental questions are what, how and why those form the basis of this paper. Any theory paper is supposed to define the basic constructs dimensions or elements constituting the framework (what), for example, in our research we have identified performance dimensions and the antecedents influencing the performance. However, in context to grounded theory research, through explicit process of content analysis methodology is provided to identify elements/variables, the methodological framework is comparatively weak to answer "how" and "why", in terms of relationships (see Sushil, 2012). However in spite of the limitation our research 
has made significant attempt to extend the similar attempts like ( Malviya and Kant, 2014) by proposing a conceptual framework after identifying research gaps on the basis of extensive review of 248 articles. The current framework is firmly grounded in organizational theories (like Knowledge Based Theory) which requires significant attentions (see Sarkis et al. 2011). Conceptual framework for GSCM is our principal contribution. In next section we will provide our

\subsection{Managerial Implications}

Our study is an attempt to propose a conceptual framework for GSCM implementation. However there are various attempts by the scholars in this direction. Our attempt is based on critical review of 248 articles to highlight the need for translating knowledge as one of the resources to implement GSCM in the organization. In this way we provide theory focused framework, which provides clear differentiation from existing frameworks and the current framework.

\subsection{Further research directions}

We feel that our effort, will certainly offer multiple research directions. In this section we have outlined some of the research directions as:

- Most of the previous studies have adopted positivism approach or interpretivism approach. However realism philosophy has not been explored particularly in operations and supply chain management related research. Although we acknowledge that interpretivism or positivism and to some extent realism in recent years, have been the philosophies mostly used by the researchers in the field of operations and supply chain management areas, nevertheless research communities need to be sensitive to accepting other philosophies;

- We further propose to build an integrated GSCM framework which integrates both forward and reverse supply chain; 
- The above framework can further be extended from contingency theory perspective. In this way the acceptability of the framework will further enhance;

- In context to conceptual framework building, we have used literature review. However, literature review in most cases in alone cannot resolve the conflict related to nature of linkages among constructs of the framework. In such case when literature review is not conclusive, graph theory methods like ISM,GTMA,TISM etc. are found to be more useful (Sushil,2012);

- There is a scope for researchers to further explore, the impact of GSCM practices on health of human beings and can further address the flora and fauna sustainability;

- Investigate the mediating effect of product complexity on GSCM performance;

- The behavioral dimensions of GSCM need further attentions;

- There is need for cross-cultural comparison of top management personality for GSCM implementation;

- The study of impacts of cultural dimensions on GSCM network need further investigation

\section{Acknowledgement}

We are grateful to the two reviewers for their constructive comments and managing editor for her support in entire review process.

\section{References}

1. Ageron, B., Gunasekaran, A., \&Spalanzani, A. (2012). Sustainable supply management: An empirical study. International Journal of Production Economics, 140(1), 168-182. 
2. Ameer, R., and Othman, R. (2012). Sustainability practices and corporate financial performance: A study based on the top global corporations. Journal of Business Ethics, 108(1), 61-79.

3. Atlas, M. and R. Florida. 1998. "Green Manufacturing." In Handbook of Technology Management, edited by R.Dorf, CRC Press.

4. Awaysheh, A. and Klassen, R. 2010, "The impact of supply chain structure on the use of supplier socially responsible practices", International Journal of Operations and Production Management,30(12),1246-1268.

5. Azevedo, S. G., Carvalho, H., \& Cruz Machado, V. (2011). The influence of green practices on supply chain performance: a case study approach.Transportation research part E: logistics and transportation review, 47(6), 850-871.

6. Azzone, G. and G. Noci.1998. "Identifying Effective PMSs for the Deployment of 'Green' Manufacturing Strategies.” International Journal of Operations and Production Management 8 (6): 308-335.

7. Bai, C. and J. Sarkis. 2010. "Greener Supplier Development: Analytical Evaluation Using Rough Set Theory." Journal of Cleaner Production, 17 (2): 255-264.

8. Baines, T., S. Brown, O. Benedettini and P. Ball. 2012. "Examining Green Production and its Role within the Competitive Strategy of Manufacturers." Journal of Industrial Engineering and Management, 15 (1): 5387.

9. Bala, A., Muñoz, P., Rieradevall, J., and Ysern, P. (2008).Experiences with greening suppliers. The universitatautonoma de barcelona. Journal of Cleaner Production, 16(15), 1610-1619.

10. Ball, P. D., Evans, S., Levers, A., and Ellison, D. (2009). Zero carbon manufacturing facility-towards integrating MEW process flows. Proc. IMechE Part B: Journal of Engineering Manufacture, 223(9), 1085-1096.

11. Barari. S., Agarwal,G., Zhang,W.J.(Chris)., Mahanty,B.

and Tiwari,M.K.(2012), "A decision framework for the analysis of green supply chain 
contracts: An evolutionary game approach", Experts systems with applications, 39 (3),2965-2976.

12. Barney, J. (1991). Firm resources and sustained competitive advantage. Journal of management, 17(1), 99-120.

13. Baumann-Chardine, E., and Botta-Genoulaz, V. (2011, August).Impacts of replenishment practices on sustainability. In World Congress.18(1),63966401.

14. Beamon, B.M. (1999).Designing the Green Supply Chain.Logistics Information Management, 12(4):332-342.

15. Berkel, V.(2007).Cleaner Production and Eco-efficiency in Australian Small Firms. International Journal of Environmental Technology and Management, 7 (5/6): 672-693.

16. Berns, M., Townend, A., Khayat, Z., Balagopal, B., Reeves, M., Hopkins, M. S., et al. (2009). The business of sustainability: what it means to managers now. Sloan Management Review, Fall, 20-26.

17. Bhardwaj, B. R. (2016). Role of green policy on sustainable supply chain management: a model for implementing corporate social responsibility (CSR). Benchmarking: An International Journal, 23(2), 456-468.

18. Bhateja, A. K., Babbar, R., Singh, S., \&.Sachdeva, A.(2012).Study of the Critical factor Finding's regarding evaluation of Green supply chain Performance of Indian Scenario for Manufacturing Sector. International Journal of Computational Engineering\& Management, 15(1), 74-80.

19. Bierma, T.J. and F.L. Wasterstraat. 1999. "Cleaner Production from Chemical Suppliers: Understanding Shared Savings Contracts. Journal of Cleaner Production 7 (2): 145-158.

20. Björklund, M., Martinsen, U., and Abrahamsson, M. (2012).Performance measurements in the greening of supply chains. Supply Chain Management: An International Journal, 17(1), 29-39.

21. Blanco,E. and Cottrill,K.(2013). Delivering on the Promise of Green Logistics. MIT Sloan Review,54(December). 
22. Blome, C., Hollos, D., and Paulraj, A.2013."Green procurement and collaboration: Antecedents and effect on supplier performance".International Journal of Production Research,52(1),32-49.

23. Boltic, Z., N. Ruzic, M. Jovanovic, M.Savic, J. Jovanovic.and S. Petrovic. 2013. Cleaner Production Aspects of Tablet Coating Process in Pharmaceutical Industry: Problem of VOCs Emission. Journal of Cleaner Production 44: 123132.

24. Bozarth, C. C., Warsing, D. P., Flynn, B. B., and Flynn, E. J. (2009).The impact of supply chain complexity on manufacturing plant performance. Journal of Operations Management, 27(1), 78-93.

25. Brandenburg. M.,K. Govindan,J.Sarkis and S.Seuring (2012)."Quantitative models for sustainable supply chain management: Developments and directions, European Journal of Operational Research, 233(2):299-312.

26. Brown,G., and Stone,L.(2007).From Cleaner Production to Sustainable Production and Consumption in Australia and New Zealand: Achievements, Challenges, and Opportunities. Journal of Cleaner Production, 15(8-9), 716-728. 27. Caniëls, M. C., Gehrsitz, M. H., and Semeijn, J. (2013). Participation of suppliers in greening supply chains: An empirical analysis of German automotive suppliers. Journal of Purchasing and supply management, 19(3), 134-143.

28. Cannella, S.amd E. Ciancimino 2010. "Up-to-date Supply Chain Management: The Coordinated (S, R) order-up-to." In Advanced Manufacturing and Sustainable Logistics, edited by W. Dangelmaier, A. Blecken, R. Delius and S. Klöpfer, 175-185. Berlin and Heidelberg: Springer.

29. Carter, C.R. and Carter, J.R. (1998), "Inter-organisational determinants of environmental purchasing: initial evidence from the consumer products industries", Decision Science, 29(3),659-84.

30. Carter, C. R., and Easton, P. L. (2011). Sustainable supply chain management: evolution and future directions. International Journal of Physical Distribution and Logistics Management, 41(1), 46-62. 
31. Carter, C.R. and Ellram, L.M. (1998), "Reverse logistics: a review of the literature and framework for future investigation", Journal of Business Logistics, 19(1),85-102.

32. Carter, C.R. and Jenning, M.M. (2002), "Social responsibility and supply chain relationships", Transportation ResearchPart E,38(1),37-52.

33. Carter, C.R. and Rogers, D.S. (2008). A framework of sustainable supply chain management: towards new theory. International Journal of Physical: Distribution and Logistics Management,38 (5),360-87.

34. Carter, C.R., Ellram, L.M. and Ready, K.J. (1998), "Environmental purchasing: benchmarking our German counterparts", International Journal of Purchasing and Materials Management,34(4),28-38.

35. Chaabane, A., A. Ramudhin and M. Paquet. 2012. "Design of Sustainable Supply Chains under Emission Trading Scheme." International Journal of Production Economics 135 (1): 37-49.

36. Chandra, C. and Tumanyan, A. (2005). Supply chain system taxonomy: a framework and methodology. Human Systems Management, 24 (4),245-58.

37. Chen, I. J., \&Paulraj, A. (2004). Towards a theory of supply chain management: the constructs and measurements. Journal of operations management, 22(2), 119-150.

38. Chen, L., Olhager, J., \& Tang, O.(2014).Manufacturing facility location and sustainability: A literature review and research agenda. International Journal of Production Economics.149(March), 154-163.

39. Chen, Y. S. (2008). The positive effect of green intellectual capital on competitive advantages of firms. Journal of Business Ethics, 77(3), 271-286.

40. Chen, C., Zhu, J., Yu, J. Y., and Noori, H. (2012).A new methodology for evaluating sustainable product design performance with two-stage network data envelopment analysis. European Journal of Operational Research, 221(2), 348-359. 
41. Chen, I.J. and A. Paluraj. 2004. "Towards a Theory of Supply Chain Management: The Constructs and Measurement." Journal of Operations Management 22 (2): 119-150.

42. Chien, M. K., and Shih, L. H. (2007).An empirical study of the implementation of green supply chain management practices in the electrical and electronic industry and their relation to organizational performances.International Journal of Environmental Science and Technology, 4(3), 383-94.

43. Choi, T. Y. and Krause, D. R. (2006). The supply base and its complexity: Implications for transaction costs, risks, responsiveness, and innovation". Journal of Operations Management, 24,637-652.

44. Choi, T. M., \& Chiu, C. H. (2012). Mean-downside-risk and meanvariance newsvendor models: implications for sustainable fashion retailing. International Journal of Production Economics, 135(2), 552-560.

45. CII-BCG Report (2013). Powering Past Headwinds - Indian Manufacturing: Winning in an era of Shocks, Swings and Shortages.Confederation of Indian Industries, India.

46. http://www.cii.in/PressreleasesDetail.aspx?enc=ebOCqBDmHr+sNILc4+ JTEwkz16CJYujdPQcvtjqNbQ8=

47. Claver-Cortes, E., Zaragoza-Saez, P., and Pertusa-Ortega, E. (2007). Organizational structure features supporting knowledge management processes. Journal of Knowledge Management, 11(4), 45-57.

48. Conner, K. R. (1991). A historical comparison of resource-based theory and five schools of thought within industrial organization economics: do we have a new theory of the firm?. Journal of management, 17(1), 121-154.

49. Corbett, C. J., and Klassen, R. D. (2006).Extending the horizons: Environmental excellence as key to improving operations.Manufacturing and Service Operations Management, 8(1), 5-22.

50. Cordeiro, J. J., and Sarkis, J. (1997). Environmental proactivism and firm performance: evidence from security analyst earnings forecasts. Business Strategy and the Environment, 6(2), 104-114.

51. Corral, M.C. 2003. "Sustainable Production and Consumption Systemscooperation for Change: Assessing and Simulating the Willingness of the Firm to Adopt/Develop Cleaner Technologies.The Case of the In-Bond Industry in Northern Mexico." Journal of Cleaner Production 11 (4): 411-426. 
52. Dada, A., Staake, T., and Fleisch, E. (2010).Reducing Environmental Impact in Procurement by Integrating Material Parameters in Information Systems: The Example of Apple Sourcing.In AMCIS (p. 369).

53. Daily, B. F., and Huang, S. C. (2001).Achieving sustainability through attention to human resource factors in environmental management. International Journal of Operations and Production Management, 21(12), 1539-1552.

54. Daily, B. F., Bishop, J. W., and Massoud, J. A. (2012).The role of training and empowerment in environmental performance: A study of the Mexican maquiladora industry. International Journal of Operations \& Production Management, 32(5), 631-647.

55. Darnall, N., G.J. Jolley and R. Handfield. 2008. "Environmental Management Systems and Green Supply Chain Management: Complements for Sustainability?" Business Strategy and the Environment 17 (1): 30-45.

56. Davis, T. (1993).Effective supply chain management. Sloan management review, 34, 35-35.

57. Deif, A.M. 2011. "A System Model for Green Manufacturing."International Journal of Cleaner Production 19 (14): 1553-1559.

58. Delmas, M., and Montiel, I. (2009). Greening the supply chain: when is customer pressure effective?. Journal of Economics and Management Strategy, 18(1), 171-201.

59. Despeisse, M., P.D., Ball, S. Evans and A. Levers. 2012. "Industrial Ecology at Factory Level - a Conceptual Model." Journal of Cleaner Production 31 (3-4): 30-39.

60. Diabat, A., and Govindan, K. (2011).An analysis of the drivers affecting the implementation of green supply chain management. Resources, Conservation and Recycling, 55(6), 659-667.

61. Digalwar, A.K.,Ashok R. Tagalpallewar, Vivek K. Sunnapwar, (2013) "Green manufacturing performance measures: an empirical investigation from 
Indian manufacturing industries", Measuring Business Excellence,17 (4),59 75.

62. Dillon, P.S. and K. Fischer, 1992.Environmental Management in Corporations: Methods and Motivations." Medford, MA:Tufts Center for Environmental Management.

63. Dubey, R., Bag, S., Ali, S. S., and Venkatesh, V. G. (2013). Green purchasing is key to superior performance: an empirical study. International Journal of Procurement Management, 6(2), 187-210.

64. Dubey.R., and Bag. S.(2013). Exploring the dimensions of sustainable practices: An empirical study on Indian manufacturing firms", International Journal of Operations and Quantitative Management, 19 (2),101-124.

65. Dubey, R., \& Ali, S. S. (2015a). Exploring antecedents of extended supply chain performance measures: an insight from Indian green manufacturing practices. Benchmarking: An International Journal, 22(5), 752-772.

66. Dubey, R., Gunasekaran, A., Papadopoulos, T., \& Childe, S. J. (2015b). Green supply chain management enablers: Mixed methods research. Sustainable Production and Consumption, 4, 72-88.

67. Dues, C.M., K.H. Tan and M. Lim. 2013. "Green as the New Lean: How to use Lean Practices as a Catalyst to Greening your Supply Chain." Journal of Cleaner Production 40: 93-100.

68. Easwaran, G., and Üster, H. (2010).A closed-loop supply chain network design problem with integrated forward and reverse channel decisions. IIE Transactions, 42(11), 779-792.

69. Eltayeb, T., Zailani, S. and Ramayah, T. (2011), "Green supply chain initiatives among certified companies in Malaysia and environmental sustainability: investigating the outcomes", Resources, Conservation and Recycling,55,495-506.

70. Erlandsson, J., and Tillman, A. M. (2009).Analysing influencing factors of corporate environmental information collection, management and communication. Journal of Cleaner Production, 17(9), 800-810. 
71. Farish, M. 2009. "Plants That Are Green: Toyota's Lean Manufacturing." Engineering and Technology 4 (3): 68-9.

72. Fawcett, S. E., Waller, M. A., Miller, J. W., Schwieterman, M. A., Hazen, B. T., \& Overstreet, R. E. (2014). A trail guide to publishing success: tips on writing influential conceptual, qualitative, and survey research. Journal of Business Logistics, 35(1), 1-16.

73. Fernández, E., Junquera, B., and Ordiz, M. (2003). Organizational culture and human resources in the environmental issue: a review of the literature. International Journal of Human Resource Management, 14(4), 634656.

74. Field, J. and R. Sroufe 2007. "The Use of Recycled Materials in Manufacturing: Implications for Supply Chain Management." International Journal of Production Research 45 (18/19): 4439-4463.

75. Fisher, M., Ramdas, K., and Ulrich, K. (1999). Component sharing in the management of product variety: A study of automotive braking systems.Management Science, 45(3), 297-315.

76. Fleischmanin, M., Beullens, P., Bloemhof-Ruwaard, J. M., and Van Wassenhove, L. N. (2001).The impact of product recovery on logistics network design. Production and Operations Management, 10(2), 156- 173

77. Florida, R. 1996. "Lean and Green: The Move to EnvironmentallyConscious Manufacturing." California Management Review 39 (1): 80-105.

78. Fuller, D. A., and Ottman, J. A. (2004).Moderating unintended pollution: the role of sustainable product design. Journal of Business Research,57(11), 1231-1238.

79. Franchetti, M., K.Bedal, J. Ulloa and S. Grodek. 2009. "Lean and Green: Industrial Engineering Methods are Natural Stepping Stones to Green Engineering." Industrial Engineer 41 (9): 24-29.

80. Gardas, B. B., and Narkhede, B. E. Exploring the Green Supply Chain management: A Technical Review. International Journal of Application or Innovation in Engineering and Management,2(5),441-450. 
81. Gavronski, I., Ferrer, G., and Paiva, E. L. (2008). ISO 14001 certification in Brazil: motivations and benefits. Journal of Cleaner Production, 16(1), 87-94. 82. Gavronski, I., Klassen, R. D., Vachon, S., and Nascimento, L. F. M. D. (2011). A resource-based view of green supply management. Transportation Research Part E: Logistics and Transportation Review, 47(6), 872-885.

83. Gavronski, I., Paiva, E. L., Teixeira, R., and de Andrade, M. C. F. (2013). ISO 14001 certified plants in Brazil-taxonomy and practices. Journal of Cleaner Production, 39, 32-41.

84. Gangele, A. and A. Verma. 2011. "The Investigation of Green Supply Chain Management Practices in Pharmaceutical Manufacturing Industry through Waste Minimization." International Journal of Industrial Engineering and Technology 3 (4): 403-415.

85. Gaussin, M., Hu, G., Abolghasem, S., Basu, S., Shankar, M. R., and Bidanda, B. (2013).Assessing the environmental footprint of manufactured products: a survey of current literature. International Journal of Production Economics, 146(2), 515-523.

86. Gilbert, S. (2000). "Greening supply chain: Enhancing competitiveness through green productivity",Report of the Top Forum on Enhancing Competitiveness through Green Productivity held in the Republic of China, 2527 May, 2000.

87. Giovanni, P.D. and V.E. Vinzi.(2012). "Covariance versus Componentbased Estimates of Performance in Green Supply Chain Management." International Journal of Production Economics 135 (2): 907-916.

88. Giovanni,P.D.2012."Do internal and external environmental management contribute to the triple bottom line?",International Journal of Operations and Production Management,32(3),265 - 290.

89. Gimenez, C., Sierra, V., and Rodon, J. (2012). Sustainable operations: Their impact on the triple bottom line. International Journal of Production Economics, 14O(1), 149-159.

90. Ginsberg, J. M., and Bloom, P. N. (2004). Choosing the right green marketing strategy. MIT Sloan Management Review, 46(1), 79-84. 
91. Godfrey, R.(1998). "Ethical purchasing: Developing the supply chain beyond the environment." in Greener Purchasing: Opportunities and Innovations, edited by T. Russel, Sheffield, England: Greenleaf Publishing: 244251.

92. Golicic, S. L., Boerstler, C. N., and Ellram, L. M. (2010).'Greening'transportation in the supply chain. MIT Sloan Management Review, 51(2), 47-55.

93. Golini, R., Longoni, A., \&Cagliano, R. (2014).Developing sustainability in global manufacturing networks: The role of site competence on sustainability performance. International Journal of Production Economics, 147, 448-459.

94. Gonzalez-Torre, P.L., Adenso-Diaz, B. and Artiba, H. (2004). "Environmental and reverse logistics policies in European bottling and packaging firms", International Journal of Production Economics, 88(1): 95-104.

95. Govindan, K., Kaliyan, M., Kannan, D., and Haq, A. N. 2014.Barriers analysis for green supply chain management implementation in Indian industries using analytic hierarchy process.International Journal of Production Economics, 147(PART B), 555-568.

96. Govindan, K., Khodaverdi, R., and Jafarian, A. 2013.A fuzzy multi criteria approach for measuring sustainability performance of a supplier based on triple bottom line approach. Journal of Cleaner Production, 47, 345-354.

97. Govindan,K., Palaniappan,M.,Zhu,Q.andKannan,D.2012.Analysis of third party reverse logistics provider using interpretive structural modeling. International Journal of Production Economics, 140(1), 204-211.

98. Govindan, K., Kannan, D., Diabat, A., Mahmoud, K., and Yong, G. (2012). A carbon footprint based reverse logistics network design model. Resources, Conservation and Recycling, 67(October), 75-79.

99. Govindarajulu, N., and Daily, B. F. (2004).Motivating employees for environmental improvement. Industrial Management and Data Systems, 104(4), 364-372. 
100. Grant, R. M. (1996). Toward a knowledge-based theory of the firm. Strategic management journal, 17, 109-122.

101. Guide Jr, V. D. R., and Van Wassenhove, L. N. (2009). OR FORUM-the evolution of closed-loop supply chain research. Operations Research, 57(1), 1018.

102. Gunasekaran, A. and Gallear, D., 2012. "Special Issue on Sustainable development of manufacturing and services", International Journal of Production Economics 140 (1).1-6.

103. Gunasekaran, A. and A.Spalanzani.2012."Sustainable of manufacturing services: Investigation for research and applications", International Journal of Production Economics, 140(1):35-47.

104. Gunasekaran, A., Irani, Z., and Papadopoulos, T. (2013).Modelling and analysis of sustainable operations management: certain investigations for research and applications. Journal of the Operational Research Society.

105. Green, K., Morton, B., and New, S. (1996). Purchasing and environmental management: interactions, policies and opportunities. Business Strategy and the Environment, 5(3), 188-197

106. Hart, S. L. (1995). A natural-resource-based view of the firm.Academy of Management Review, 20(4), 986-1014.

107. Hart, S. L. (1997). Beyond greening: Strategies for a sustainable world.Harvard Business Review, 75(1), 66-76.

108. Hassini, E., Surti, C., and Searcy, C. (2012). A literature review and a case study of sustainable supply chains with a focus on metrics. International Journal of Production Economics, 140(1), 69-82.

109. Helfat, C. E., \&Teece, D. J. (1987). Vertical integration and risk reduction. JL Econ. \& Org., 3, 47.

110. Hervani, A. A., Helms, M. M., \& Sarkis, J. (2005).Performance measurement for green supply chain management. Benchmarking: An International Journal, 12(4), 330-353.

111. Hoejmose, S. U., and Adrien-Kirby, A. J. (2012). Socially and environmentally responsible procurement: A literature review and future research agenda of a managerial issue in the 21 st century. Journal of Purchasing and Supply Management, 18(4), 232-242. 
112. Hollos, D., C. Blome and K. Foerstl 2012."Does sustainable supplier cooperation affect performance? Examining implications for the triple bottom line." International Journal of Production Research,50(11),2968-2986.

113. Holt,D., and Ghobadian,A.(2009) "An empirical study of green supply chain management practices amongst UK manufacturers", Journal of Manufacturing Technology Management, 20(7),933 - 956.

114. Hopkins, M. S. (2009). What executives don't get about sustainability (and further notes on the profit motive). MIT Sloan management review, 51(1), $35-40$.

115. Hsu, C.W. and Hu, A.H. 2008. "Green Supply Chain Management in the Electronic Industry."International Journal of Science and Technology, 5 (2): 205216.

116. Hsu, C.W. and Hu.A.H.2009."Applying Hazardous Substance Management to Supplier Selection Using Analytic Network Process." Journal of Cleaner Production 17 (2): 255-264.

117. Houe, R., \&Grabot, B. (2009). Assessing the compliance of a product with an eco-label: From standards to constraints. International Journal of Production Economics, 121(1), 21-38.

118. Hu, A. H., Hsu, C. W., and Chen, S. H. (2010).Incorporating carbon management into supplier selection in the green supply chain: evidence from an electronics manufacturer in Taiwan.In Proceedings of 16th annual international sustainable development research conference.Hong Kong.

119. Hu, S. J., Zhu, X., Wang, H., and Koren, Y. (2008).Product variety and manufacturing complexity in assembly systems and supply chains. CIRP Annals-Manufacturing Technology, 57(1), 45-48.

120. Hua, L. and P.M. Bentler. 1999. "Cutoff Criteria for Fit Indexes in Covariance Structure Analysis: Conventional Criteria versus New Alternatives." Structural Equation Modeling 6(1): 1-55.

121. Huber, G. P.,Daft, R. L.(Jablin, F. M. (Ed); Putnam, L. L. (Ed); Roberts, K. H. (Ed); Porter, L. W. (Ed)) (1987).Handbook of organizational communication: 
An interdisciplinary perspective.(130-164).Thousand Oaks, CA, US: Sage Publications

122. Jabbour, A. B. L. S., Jabbour, C. J. C., Sarkis, J., and Govindan, K. (2013). Brazil's new national policy on solid waste: challenges and opportunities. Clean Technologies and Environmental Policy, 1-3.

123. Jabbour, C. J. C., and Santos, F. C. A. (2008). Relationships between human resource dimensions and environmental management in companies: proposal of a model. Journal of Cleaner Production, 16(1), 51-58.

124. Jacobs, M. A., and Swink, M. (2011). Product portfolio architectural complexity and operational performance: Incorporating the roles of learning and fixed assets. Journal of Operations Management, 29(7), 677-691.

125. Jacobs, M. A. (2013). Complexity: Toward an empirical measure. Technovation, 33(4), 111-118.

126. Jayaraman, V., Guide Jr, V. D. R., and Srivastava, R. (1999).A closedloop logistics model for remanufacturing. Journal of the operational research society, 497-508.

127. Jayaram, J., \& Avittathur, B. (2015). Green supply chains: A perspective from an emerging economy. International Journal of Production Economics, 164, 234-244.

128. Jiang, R. J., and Bansal, P. (2003).Seeing the need for ISO 14001. Journal of Management Studies, 4O(4), 1047-1067.

129. Johansson, G. and M. Winroth 2009. "Lean vs. Green Manufacturing: Similarities and Differences." In Implementation: Realizing Operations Management Knowledge Proc. of the 16th International Annual EurOMA Conference, June 14-17, Göteborg, Sweden.

130. Kabir, G., and Madugu, A. I. (2010). Assessment of environmental impact on air quality by cement industry and mitigating measures: A case study. Environmental monitoring and assessment, 160(1-4), 91-99.

131. Kassolis, M. G. (2007). The diffusion of environmental management in Greece through rationalist approaches: driver or product of globalisation?. Journal of Cleaner Production, 15(18), 1886-1893.

132. Kauppi, K. (2013). Extending the use of institutional theory in operations and supply chain management research-review and research suggestions. 
International Journal of Operations and Production Management, 33(10), 13181345.

133. Kekre, S., and Srinivasan, K. (1990). Broader product line: a necessity to achieve success?. Management science, 36(10), 1216-1232.

134. Ketchen, D. J., \& Hult, G. T. M. (2007). Bridging organization theory and supply chain management: The case of best value supply chains. Journal of Operations Management, 25(2), 573-580.

135. Kim, J. H., Youn, S., \&Roh, J. J. (2011). Green supply chain management orientation and firm performance: evidence from South Korea. International Journal of Services and Operations Management, 8(3), 283304.

136. Kim, J., Park, K., Hwang, Y., and Park, I. (2010). Sustainable manufacturing: A case study of the forklift painting process. International Journal of Production Research, 48(10), 3061-3078.

137. Kleiner, A. (1991). What does it mean to be green? Harvard Business Review, 69(4), 38-47.

138. Ko, H. J., and Evans, G. W. (2007). A genetic algorithm-based heuristic for the dynamic integrated forward/reverse logistics network for 3PLs. Computers and Operations Research, 34(2), 346-366.

139. Krikke, H., Bloemhof-Ruwaard, J., and Van Wassenhove, L. N. (2003). Concurrent product and closed-loop supply chain design with an application to refrigerators.International journal of production research, 41(16), 3689-3719.

140. Krishnan, V., and Gupta, S. (2001).Appropriateness and impact of platform-based product development. Management Science, 47(1), 52-68.

141. Ku, C. Y., Chang, C. T., and Ho, H. P. (2010).Global supplier selection using fuzzy analytic hierarchy process and fuzzy goal programming. Quality and Quantity, 44(4), 623-640.

142. Kumar, R. and R.Chandrakar. 2012. "Overview of Green Supply Chain Management: Operation and Environmental Impact at Different Stages of the Supply Chain." International Journal of Engineering and Advanced Technology 1 (3): 1-6. 
143. Kumar, S., and Putnam, V. (2008). Cradle to cradle: Reverse logistics strategies and opportunities across three industry sectors. International Journal of Production Economics, 115(2), 305-315.

144. Kumar, S., S. Teichman and T. Timpernagel 2012. "A green supply chain is a requirement for profitability." International Journal of Production Research, 50(5), 1278-1296.

145. Kogg, B. (2003), "Greening a cotton-textile supply chain: a case study of the transition towards organic production without a powerful force company", Greener Management International, 43:53-65.

146. Laosirihongthong,T.,Adebanjo,D. and Tan,K.C.(2013) "Green supply chain management practices and performance", Industrial Management and Data Systems, 113 (8), 1088 - 1109.

147. Large, R. O., \&Gimenez Thomsen, C. (2011). Drivers of green supply management performance: Evidence from Germany. Journal of Purchasing and Supply Management, 17(3), 176-184.

148. Law, K. M., and Gunasekaran, A. (2012). Sustainability development in high-tech manufacturing firms in Hong Kong: Motivators and readiness. International Journal of Production Economics, 137(1), 116-125.

149. Lee, D. H., and Dong, M. (2008).A heuristic approach to logistics network design for end-of-lease computer products recovery. Transportation Research Part E: Logistics and Transportation Review, 44(3), 455-474.

150. Lee, S.M., Kim, S.T. and Choi, D. (2012), "Green supply chain management and organizational performance", Industrial Management and Data Systems, Vol. 112 No. 8, pp. 1148-1180.

151. Li, S., B.Nathan, T.S. Ragu-Nathan and S.S.Rao. 2006. "The Impact of Supply Chain Management Practices on Competitive Advantage and Organizational Performance." Omega 34 (2): 107-124.

152. Lightfoot,H.,Baines,T. and Smart,P.(2013)."The servitization of manufacturing".International Journal of Operations and Productions Management,33(11/12):1408-1434. 
153. Linton, J. D., Klassen, R., and Jayaraman, V. (2007). Sustainable supply chains: an introduction. Journal of Operations Management, 25(6), 1075-1082. 154. Lippmann, S. (1999). Supply chain environmental management: elements for success. Corporate Environmental Strategy, 6(2), 175-182.

155. López-Gamero, M. D., Molina-Azorín, J. F., and Claver-Cortés, E. (2010).The potential of environmental regulation to change managerial perception, environmental management, competitiveness and financial performance. Journal of Cleaner Production, 18(10), 963-974.

156. Lu, L. Y. Y., Wu, C. H., and Kuo, T. (2007). Environmental principles applicable to green supplier evaluation by using multi-objective decision analysis. International Journal of Production Research, 45(18-19), 4317-4331.

157. Lu, Z., and Bostel, N. (2007). A facility location model for logistics systems including reverse flows: The case of remanufacturing activities. Computers and Operations Research, 34(2), 299-323.

158. Luthra, S., Kumar, V., Kumar, S., \&Haleem, A. (2011). Barriers to implement green supply chain management in automobile industry using interpretive structural modeling technique: An Indian perspective. Journal of Industrial Engineering and Management, 4(2), 231-257.

159. Luthra, S., Garg, D., \& Haleem, A. (2015). Critical success factors of green supply chain management for achieving sustainability in Indian automobile industry. Production Planning \& Control, 26(5), 339-362.

160. Mahler, D. (2007). The sustainable supply chain. Supply Chain Management Review, 11(8), 59-60.

161. Maignan, I., and Mcalister, D. T. (2003). Socially responsible organizational buying: how can stakeholders dictate purchasing policies?. Journal of Macromarketing, 23(2), 78-89.

162. Malviya, R. K., \& Kant, R. (2015). Green supply chain management (GSCM): a structured literature review and research implications. Benchmarking: An International Journal, 22(7), 1360-1394.

163. Mangla, S., Madaan, J., and Chan, F. T. (2013).Analysis of flexible decision strategies for sustainability-focused green product recovery system.International Journal of Production Research, 51(11), 3428-3442. 
164. Marin, A., and Pelegrin, B. (1998). The return plant location problem: Modelling and resolution. European Journal of Operational Research, 104(2), 375-392.

165. Markley, M. J., \& Davis, L. (2007).Exploring future competitive advantage through sustainable supply chains. International Journal of Physical Distribution \& Logistics Management, 37(9), 763-774.

166. Massoud, J. A., Daily, B. F., and Bishop, J. W. (2011). Perceptions of environmental management systems: an examination of the Mexican manufacturing sector. Industrial Management and Data Systems, 111(1), 5-19.

167. Mathiyazhagan, K., Govindan, K., and NoorulHaq, A.2014. "Pressure analysis for green supply chain management implementation in Indian industries using analytic hierarchy process".International Journal of Production Research.doi: 10.1080/00207543.2013.831190

168. Mathiyazhagan, K., Govindan, K., NoorulHaq, A., and Geng, Y.2013. "An ISM approach for the barrier analysis in implementing green supply chain management". Journal of Cleaner Production, 47, 283-297.

169. Melnyk, S. A., and Smith, R. T. (1996). Green Manufacturing, Society for Manufacturing Engineering. Dearborn, MI.

170. Miles, M. P., and Covin, J. G. (2000). Environmental marketing: A source of reputational, competitive, and financial advantage. Journal of Business Ethics, 23(3), 299-311.

171. Min, H., and Ko, H. J. (2008). The dynamic design of a reverse logistics network from the perspective of third-party logistics service providers. International Journal of Production Economics, 113(1), 176-192.

172. Min, H., and Galle, W. P. (1997). Green purchasing strategies: trends and implications. Journal of Supply Chain Management, 33(3), 10-17.

173. Mitra, S., and Datta, P. P. (2014). Adoption of green supply chain management practices and their impact on performance: an exploratory study of Indian manufacturing firms. International Journal of Production Research, 52(7):2085-2107. 
174. Mohanty, R. P., and Deshmukh, S. G. (1998). Managing green productivity: Some strategic directions. Production Planning and Control, 9(7), 624-633.

175. Mohanty, M.K. and P.Gahan. 2012. "Buyer Supplier Relationship in Manufacturing Industry - Findings from Indian Manufacturing Sector." Business Intelligence Journal 5 (2): 319-333.

176. Mohanty, R. P., \& Prakash, A. (2014a). Green supply chain management practices in India: an empirical study. Production Planning \& Control, 25(16), 1322-1337.

177. Mohanty, R. P., \& Prakash, A. (2014b). Green supply chain management practices in India: a confirmatory empirical study. Production \& Manufacturing Research, 2(1), 438-456.

178. Mollenkopf,D.,Stolze,H. and Tate,W.L. and Ueltschy,M.(2010) "Green, lean, and global supply chains", International Journal of Physical Distribution and Logistics Management, 40(1/2), $14-41$.

179. Mooi,E. and M.Serstedt (2011). "A concise Guide to Market Research", Springer-Verlag, Berlin Hiedelberg.

180. Muduli, K., and Barve, A. (2013). Sustainable development practices in mining sector: a GSCM approach. International Journal of Environment and Sustainable Development, 12(3), 222-243.

181. Muduli, K., Govindan, K., Barve, A., and Geng, Y.(2013).Barriers to green supply chain management in Indian mining industries: A graph theoretic approach. Journal of Cleaner Production, 47, 335-344.

182. Muduli, K., Govindan, K., Barve, A., Kannan, D., and Geng, Y.(2013a).Role of behavioural factors in green supply chain management implementation in Indian mining industries.Resources, Conservation and Recycling, 76(July), 50-60.

183. Mukherjee, K. (2010). Measuring energy efficiency in the context of an emerging economy: The case of Indian manufacturing.European Journal of Operational Research, 201(3), 933-941. 
184. Murovec, N., R.S.Erker, and I. Prodan, 2012. "Determinants of Environmental Investments: Testing the Structural Model." Journal of Cleaner Production 37: 265-277.

185. Murphy, P.R. and Poist, R.F. (2000), "Green logistics strategies: an analysis of usage patterns", Transportation Journal,40 (2),5-16.

186. Murphy, P.R., Poist, R.F. and Braunschwieg, C.D. (1994), "Management of environmental issues in logistics: current status and future potential", Transportation Journal, 34(1),48-56.

187. Murphy, P.R., Poist, R.F. and Braunschwieg, C.D. (1995), "Role and relevance of logistics to corporate environmentalism: an empirical assessment", International Journal of Physical Distribution and Logistics Management, 25 (2), 5-19.

188. Narasimhan, R., and Carter, J. R. (1998).Linking business unit and material sourcing strategies. Journal of Business Logistics, 19(2), 155-171.

189. Narula,S.A. and Upadhyay,K.M.(2011).Product strategy vis-àvis environment: are strategies of pesticide manufacturers in India sustainable?", Social Responsibility Journal,7(2),282 - 294.

190. Nelson, D., Marsillac, E., and Rao, S. (2013). Antecedents and Evolution of the Green Supply Chain. Journal of Operations and Supply Chain Management, 1(1), 29-43.

191. Nouira, I., \&Frein, Y. (2014).Optimization of manufacturing systems under environmental considerations for a greenness-dependent demand. International Journal of Production Economics.

192. O’Brien, C. (1999). Sustainable production - a new paradigm for the millennium.International Journal of Production Economics, 60-61, 1-7.

193. Olugu, E. U., Wong, K. Y., and Shaharoun, A. M. (2011). Development of key performance measures for the automobile green supply chain. Resources, Conservation and Recycling, 55(6), 567-579.

194. Ouchi, W. G. (1980). Markets, bureaucracies, and clans. Administrative science quarterly, 25(1). 
195. Park, J., Sarkis, J., and Wu, Z. (2010). Creating integrated business and environmental value within the context of China's circular economy and ecological modernization. Journal of Cleaner Production, 18(15), 1494-1501.

196. Pauli, G. 1997. "Zero Emissions: The Ultimate Goal of Cleaner Production." Journal of Cleaner Production 5 (1/2): 109-113.

197. Paulraj, A., and de Jong, P.2011."The effect of ISO 14001 certification announcements on stock performance". International Journal of Operations and Production Management, 31(7), 765-788.

198. Paulraj, A. (2009). Environmental motivations: a classification scheme and its impact on environmental strategies and practices. Business Strategy and the Environment, 18(7), 453-468.

199. Pereira-Moliner, J., E. Claver-Cortes, J. Molina-Azorin and J. Tari. 2012. “Quality Management, Environmental Management and Firm Performance: Direct and Mediating Effects in the Hotel Industry." Journal of Cleaner Production 37: 82-92.

200. Pittaway, L., Robertson, M., Munir, K., Denyer, D., and Neely, A. (2004). Networking and innovation: a systematic review of the evidence. International Journal of Management Reviews, 5(3-4), 137-168.

201. Pochampally, K. K., Gupta, S. M., \& Govindan, K. (2009). Metrics for performance measurement of a reverse/closed-loop supply chain. International Journal of Business Performance and Supply Chain Modelling, 1(1), 8-32.

202. Podsakoff, P.M., S.B. MacKenzie J.-Y.Lee and N.P.Podsakoff. 2003. "Common Method Biases in Behavioral Research: A Critical Review of the Literature and Recommended Remedies." Journal of Applied Psychology 88: 879-903.

203. Polcari, M. R. (2007). A total approach to industry sustainability. Semiconductor International, 30(1), 108-108.

204. Porter, M. E., and van der Linde, C. (1995). Green and competitive. Harvard Business Review, 73(5), 120-134.

205. Prajogo, D., Chowdhury, M., Yeung, A. C., and Cheng, T. C. E. (2012). The relationship between supplier management and firm's operational 
performance: a multi-dimensional perspective. International Journal of Production Economics, 136(1), 123-130.

206. QS World University Rankings

(2015).

http://www.topuniversities.com/university-rankings-articles/world-universityrankings/qs-world-university-rankings-methodology (Date of access: $15^{\text {th }}$ April, 2016).

207. Quelch, J. A., and Kenny, D. (1994). Extend profits, not product lines. Harvard Business Review, 72(5), 153-160.

208. Rao,P. and Holt,D.(2005)."Do green supply chains lead to competitiveness and economic performance?", International Journal of Operations and Production Management, 25(9), 898 - 916.

209. Ramdas, K., and Sawhney, M. S. (2001). A cross-functional approach to evaluating multiple line extensions for assembled products. Management Science, 47(1), 22-36.

210. Rodrigue, J. P., Slack, B., and Comtois, C. (2001).Green logistics (the paradoxes of). The Handbook of Logistics and Supply-Chain Management, 2.

211. Rosen, C. M., Beckman, S. L., and Bercovitz, J. (2002). The Role of Voluntary Industry Standards in Environmental Supply-Chain Management. Journal of Industrial Ecology, 6(3-4), 103-123.

212. Routroy, S., \&Pradhan, S. K. (2012). Framework for green procurement: a case study. International Journal of Procurement Management, 5(3), 316-336.

213. Salam, M. A. (2008, December). Green procurement adoption in manufacturing supply chain.In Proceedings of the 9th Asia Pasific Industrial Engineering and Management Systems Conference (pp. 1253-1260).

214. Salancik, G. R., \&Pfeffer, J. (1978).A social information processing approach to job attitudes and task design. Administrative science quarterly, 224-253.

215. Salvador, F., Forza, C., and Rungtusanatham, M. (2002). Modularity, product variety, production volume, and component sourcing: theorizing beyond generic prescriptions. Journal of Operations Management, 20(5), 549575. 
216. Sarkis, J. (1998). Evaluating environmentally conscious business practices.European journal of operational research, 107(1), 159-174.

217. Sarkis, J., Zhu, Q., and Lai, K., 2011. An organizational theoretic review of green supply chain management literature.International Journal of Production Economics 130(1), 1-15.

218. Sarkis, J. 2003. "A Strategic Decision Framework for Green Supply Chain Management." Journal of Cleaner Production 11 (4): 397-409.

219. Sarkis, J., Zhu, Q., and Lai, K. H. (2011).An organizational theoretic review of green supply chain management literature. International Journal of Production Economics, 130(1), 1-15.

220. Sathaye, N., Horvath, A., and Madanat, S. (2010). Unintended impacts of increased truck loads on pavement supply-chain emissions. Transportation Research Part A: Policy and Practice, 44(1), 1-15.

221. Schoenherr, T., Hilpert, D., Soni, A. K., Venkataramanan, M. A., and Mabert, V. A. (2010). Enterprise systems complexity and its antecedents: a grounded-theory approach. International Journal of Operations and Production Management, 30(6), 639-668.

222. Schoenherr, T. and V.A. Mabert. 2011. "An Exploratory STUDY of procurement Strategies for Multi-item RFQs in B2B Markets: Antecedents and Impact on Performance," Production and Operations Management 20 (3): 214 234.

223. Schrettle,S.,Hinz,A.,Scherrer-Rathje,M. and Freidli,T.(2014), "Turning sustainability into action: Explaining firms' sustainability efforts and their impact on firm performance", International Journal of Production Economics, 147(A),73-84.

224. Scipioni, A., Manzardo, A., Mazzi, A., and Mastrobuono, M. (2012).Monitoring the carbon footprint of products: a methodological proposal. Journal of Cleaner Production, 36, 94-101.

225. Seman, N. A. A., Zakuan, N., Jusoh, A., Arif, M. S. M., \&.Saman, M. Z. M. (2012).Green Supply Chain Management: A review and research direction. International Journal of Managing Value \& Supply Chains, 3(1),1-18. 
226. Seuring, S. and M. Muller. 2008. "From a Literature Review to a Conceptual Framework for Supply Chain Management." Journal of Cleaner Production 16 (15): 1699-1710.

227. Seyfang, G. (2006). Ecological citizenship and sustainable consumption: Examining local organic food networks. Journal of rural studies, 22(4), 383-395. 228. Shang, K. C., Lu, C. S., and Li, S. (2010). A taxonomy of green supply chain management capability among electronics-related manufacturing firms in Taiwan. Journal of environmental management, 91(5), 1218-1226.

229. Sheriff, K. M., Gunasekaran, A., and Nachiappan, S. (2012). Reverse logistics network design: a review on strategic perspective. International Journal of Logistics Systems and Management, 12(2), 171-194.

230. Sheu, J. B., Chou, Y. H., and Hu, C. C. (2005).An integrated logistics operational model for green-supply chain management. Transportation Research Part E: Logistics and Transportation Review, 41(4), 287-313.

231. Sheu, J. B., and Chen, Y. J. (2012).Impact of government financial intervention on competition among green supply chains. International Journal of Production Economics, 138(1), 201-213.

232. Shi, V. G., Koh, S. L., Baldwin, J., and Cucchiella, F. (2012). Natural resource based green supply chain management. Supply Chain Management: An International Journal, 17(1), 54-67.

233. Siaminwe, L., K.Chinsembu and M. Syakalima. 2005. "Policy and Operational Constraints for the Implementation of Cleaner Production." Journal of Cleaner Production 13: 1037-1047.

234. Sikdar, S.K. and S.G. Howell. 1998. "On Developing Cleaner Organic Unit Processes." Journal of Cleaner Production 6 (3): 253-259.

235. Simpson,D.,Power,D. and Samson,D. (2007).Greening the automotive supply chain: a relationship perspective. International Journal of Operations and Production Management,27(1),28 - 48.

236. Singh, A., B. Singh and A.K. Dhingra. 2012. "Drivers and Barriers of Green Manufacturing Practices: A Survey of Indian Industries." International Journal of Engineering Sciences 1 (1): 5-19. 
237. Singh, L.P. 2011. "Role of Logistics and Transportation in Green Supply Chain Management: An Exploratory Study of Courier Service Industry in India." International Journal of Advanced Engineering Technology 2 (1): 260269.

238. Soleimani, H., Seyyed-Esfahani, M., and Govindan, K. (2014).Incorporating risk measures in closed-loop supply chain network design. International Journal of Production Research, 52(6), 1843-1867.

239. Srivastava, S.K. 2007. “Green Supply Chain Management: A State of the art Literature Review." International Journal of Management Reviews 9 (1): 5380.

240. Stefan, A., \& Paul, L. (2008). Does it pay to be green? A systematic overview. The Academy of Management Perspectives, 22(4), 45-62.

241. Stone, L.J. 2006."Limitations of Cleaner Production Programmes as Organizational Change Agents.II Leadership, Support, Communication, Involvement and Programme Design." Journal of Cleaner Production 14: 15-30.

242. Sutherland, J. W., Rivera, J. L., Brown, K. L., Law, M., Hutchins, M. J., Jenkins, T. L., and Haapala, K. R. (2008).Challenges for the manufacturing enterprise to achieve sustainable development. In Manufacturing Systems and Technologies for the New Frontier (pp. 15-18). Springer London.

243. Sutor, L. (2007). Green manufacturing comes of age. Control Engineering, 54(11), 69-72.

244. Sundarakani, B., De Souza, R., Goh, M., Wagner, S.M., and Manikandan, S., 2010.Modelling carbon footprints across the supply chain. International Journal of Production Economics 128(1), 43-50.

245. Sushil(2012). "Interpreting the Interpretive Structural Model".Global Journal of Flexible Systems Management, 13(2):87-106.

246. Szekely, F., \&Knirsch, M. (2005). Responsible leadership and corporate social responsibility:: Metrics for sustainable performance. European Management Journal, 23(6), 628-647.

247. Testa, F. and F. Iraldo. 2010. "Shadows and Lights of GSCM (Green Supply Chain Management): Determinants and Effects of these Practices Based on a Multinational Study." Journal of Cleaner Production 18 (10/11): 953-962. 
248. Tibben-Lembke, R. S. (2002). Life after death: reverse logistics and the product life cycle. International Journal of Physical Distribution \& Logistics Management, 32(3), 223-244.

249. Todd, N. 1994.From Eco-cities to Living Machines: Principles of Ecological Design, Berkeley, CA: North Atlantic Books.

250. Tranfield, D., Denyer, D. and Smart, P. 2003."Towards a methodology for developing evidence-informed management knowledge by means of a systematic review", British Journal of Management, 14(3),207-222.

251. Tripathi, S., and Petro, G. (2011).Evolving Green Procurement and Sustainable Supply Chain Practices in the Organizations: A Framework to Align Functional Strategy Implementation to Organization's Corporate Social Responsibility (CSR) Objectives. Management Convergence, 1(1), 24-32.

252. Tsoulfas, G.T. and C.P.Pappis. 2006. "Environmental Principles Applicable To Supply Chains Design and Operation." Journal of Cleaner Production 14 (1): 1593-1602.

253. Turner, M., and Houston, P. (2009). Going green? Start with sourcing. Supply Chain Management Review, 13(2).

254. UNEP (Fischer-Kowalski, M., Swilling, M., von Weizsäcker, E.U., Ren, Y.,Moriguchi, Y., Crane, W., Krausmann, F., Eisenmenger, N., Giljum, S., Hennicke, P.,RomeroLankao, P., SiribanManalang, A.) (2011).Decoupling natural resource use and environmental impacts from economic growth, A Report of the Working Group on Decoupling to the International Resource Panel.

255. Vachon, S. 2007. "Green Supply Chain Practices and the Selection of Environmental Technologies."International Journal of Production Research 45 (18-19): 4357-79.

256. Vachon, S. and R.D. Klassen. 2006. "Green Project Partnership in the Supply Chain: The Case of the Package Printing Industry." Journal of Cleaner Production 14 (6/7): 661-671. 
257. vanAken, J. E. (2005). Management research as a design science: articulating the research products of mode 2 knowledge production in management. British journal of management, 16(1), 19-36.

258. vanBommel, H. (2011). A conceptual framework for analyzing sustainability strategies in industrial supply networks from an innovation perspective. Journal of Cleaner Production, 19(8), 895-904.

259. Van Hoek, R. I. (1998). "Measuring the unmeasurable"-measuring and improving performance in the supply chain. Supply Chain Management: An International Journal, 3(4), 187-192.

260. van Hoof, B., and Lyon, T. P. (2013). Cleaner production in small firms taking part in Mexico's Sustainable Supplier Program. Journal of Cleaner Production, 41, 270-282.

261. Wagner, M.andSchaltegger, S. (2004).The effect of corporate environmental strategy choice and environmental performance on competitiveness and economic performance:: an empirical study of EU manufacturing. European Management Journal, 22(5), 557-572.

262. Walker, H., and Phillips, W. (2009). Sustainable procurement: emerging issues. International Journal of Procurement Management, 2(1), 41-61.

263. Wang, Z., and Sarkis, J. (2013).Investigating the relationship of sustainable supply chain management with corporate financial performance. International Journal of Productivity and Performance Management, 62(8), 871-888.

264. Wang, S. S., Zhou, D. Q., Zhou, P., \& Wang, Q. W. (2011). CO2 emissions, energy consumption and economic growth in China: A panel data analysis. Energy Policy, 39(9), 4870-4875.

265. Wee, Y. S., and Quazi, H. A. (2005). Development and validation of critical factors of environmental management. Industrial Management and Data Systems, 105(1), 96-114.

266. Wernet, G., Conradt, S., Isenring, H. P., Jimenez-Gonzalez, C., and Hungerbuhler, K. (2010). Life cycle assessment of fine chemical production: A 
case study of pharmaceutical synthesis. International Journal of Life Cycle Assessment, 15(3), 294-303.

267. Wernerfelt, B. (1984). A resource-based view of the firm. Strategic management journal, 5(2), 171-180.

268. Whitelock, V. G. (2012). Alignment between green supply chain management strategy and business strategy. International Journal of Procurement Management, 5(4), 430-451.

269. Wong, C. W., Lai, K. H., Shang, K. C., Lu, C. S., \& Leung, T. K. P. (2012). Green operations and the moderating role of environmental management capability of suppliers on manufacturing firm performance. International Journal of Production Economics, 14O(1), 283-294.

270. Wu, G. C., Ding, J. H., and Chen, P. S. (2012).The effects of GSCM drivers and institutional pressures on GSCM practices in Taiwan's textile and apparel industry. International Journal of Production Economics, 135(2), 618636.

271. Yang, C. L., Lin, S. P., Chan, Y. H., and Sheu, C. (2010).Mediated effect of environmental management on manufacturing competitiveness: An empirical study.International Journal of Production Economics, 123, 210-220.

272. Yen, Y. X., and Yen, S. Y. (2012).Top-management's role in adopting green purchasing standards in high-tech industrial firms. Journal of Business Research, 65(7), 951-959.

273. Yusuf,Y.Y.,Gunasekaran,A.,Musa,A.,EI-Berishy,N.M.,Abubakar,T. and Ambursa,H.M.(2013), "The U.K oil and gas supply chains: An empirical analysis of adoption of sustainable measures and performance outcomes", International Journal of Production Economics, 146(2),501-514.

274. Zailani, S., Jeyaraman, K., Vengadasan, G., and Premkumar, R. (2012). Sustainable supply chain management (SSCM) in Malaysia: A survey.International Journal of Production Economics, 140(1), 330-340.

275. Zeng, S.X., X.H.Meng, H.T. Yin, C.M. Tam and L. Sun. 2010."Impact of Cleaner Production on Business Performance." Journal of Cleaner Production 18 (10/11): 975-983. 
276. Zenger, T. R., \&Hesterly, W. S. (1997). The disaggregation of corporations: Selective intervention, high-powered incentives, and molecular units.Organization Science, 8(3), 209-222.

277. Zhang, F., M. Rio, R. Allais, P.ZwoLinski, T.R. Carrillo, L.Roucoules, E. Mercier-Laurent and N. Buclet. 2013. "Toward a Systematic Navigation Framework to Integrate Sustainable Development into the Company." Journal of Cleaner Production.Available online 21 May 2013.

278. Zhu, Q. and Sarkis, J. (2004), "Relationships between operational practices and performance among early adopters of green supply chain management practices in Chinese manufacturing companies", Journal of Operations management, 22(3),265-289.

279. Zhu, Q., J. Sarkis and Y.Geng. 2005. "Green Supply Chain Management in China: Pressure, Practices and Performance." International Journal of Operations and Production Management 25 (5): 449-468.

280. Zhu, Q. and J. Sarkis. 2007. “The Moderating Effects of Institutional Pressures on Emergent Green Supply Chain Practices and Performance." International Journal of Production Research 45 (18-19): 4333-55.

281. Zhu, Q., Sarkis, J. and Lai, K.-H. (2008), "Confirmation of a measurement model for green supply chain management practices implementation", International Journal of Production Economics, 111(2),261-273. 282. Zhu, Q., Geng, Y., Fujita, T. and Hashimoto, S. (2010), "Green supply chain management in leading manufacturers: case studies in Japanese large companies", Management Research Review,33(4),380-392.

283. Zhu,Q., J. Sarkis, and K.H. Lai. 2012. "Examining the Effects of Green Supply Chain Management Practices and their Mediations on Performance Improvements." International Journal of Production Research 50 (5): 1377-94.

284. Zsidisin, G., S. Melnyk and G.Ragatz. 2005. "An Institutional Theory Perspective of Business Continuity Planning for Purchasing and Supply Management.” International Journal of Production Research 43 (16): 3401-20. 
1

2

3

4

5

6

7

11

12

13

14

15

16

17

18

19

20

21

22

23

24

25

26

27

28

29

30

31

32

33

34

35

36

37

38

39

40

41

42

43

44

45

46

47

48

49

50

51

52

53

54

55

56

57

58

59

60 